\title{
Interpreting Subsidiarity - How to develop into a constitutional principle?
}

\author{
Samantha Gernat
}

\section{Introduction}

The principle of subsidiarity is clearly one of the most ambiguous and disputed notions of European Union (EU) law.' What started with the intention to create a simple mechanism that allocates competences to the Member States' or EU level, in order to ensure that the level of government, best suited to pursue the task decided, so that legislation was enacted as close as possible to the citizens, ended in confusion. ${ }^{2}$ Since the question of allocation is inherently political it was quite unclear how much of a legal component was embedded in the principle. ${ }^{3}$

Even 30 years after its first appearance, and strong efforts in academic literature to operationalize the principle, it seems that Europe has still not found a workable mechanism. In his Political Guidelines, Commission President Barroso called for the development of a 'much clearer doctrine of how we decide when action needs to be taken at EU level [and] where the balance should lie between EU level tools and national level tools'. ${ }^{4}$ In times, where EU legislation is ever expanding touching upon all fields of law it is of utmost importance to define subsidiarity in such a manner, that it can protect national autonomy where necessary while enabling the EU to act on behalf and to the benefit of all MS.

The low efficiency of the principle in reality is primarily due to the European Court

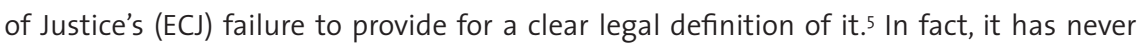
annulled a measure on grounds of subsidiarity and generally reviews the principle marginally and cautiously. ${ }^{6}$ Without the threat of annulment, the Commission has been careless in its justification for subsidiarity compliance of a legislative proposal. ${ }^{7}$ In order to

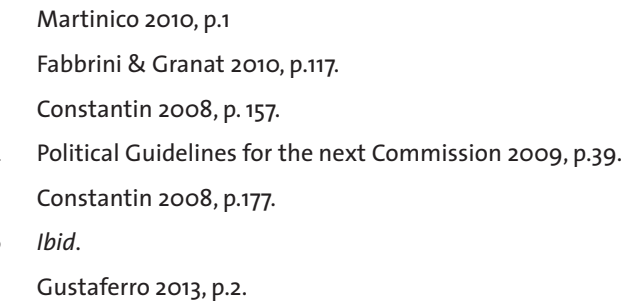


enhance control, the Treaty of Lisbon has introduced an ex ante review of compliance by national parliaments (NP). ${ }^{8}$ Although this can potentially protect national 'territory' from a competence creep, the review's full potential cannot be harnessed if lack of a uniform and efficient principle remains.

Nevertheless, an interpretation of subsidiarity is also ultimately a question of governance as both relate to the issue of how the powers of the EU and the Member States should be applied. Even if a proper definition is found, should it be the EU or the Member States who decide to whom competence should be allocated? Is it the Member States, because they have conferred the powers in the first place or the Union due to its supranational character?

As a consequence, this paper will address the question of how the principle of subsidiarity should be interpreted in order to form a workable mechanism that ensures an effective divide between EU and Member States' competence?

In search of objective criteria four theories have been selected in Section 1 of this paper which approaches subsidiarity from a legal angle. In contrast to political or economic theories, they have the value that they could be used by the Court in the future. The criteria to select the legal theories were their vast treatment in academic literature and the degree of connection to practice. This section will provide an overview about theoretical interpretation of subsidiarity and the state of play in academia.

Subsequently in Section 2, a look will be taken at two main actors in the review of subsidiarity, namely the Court and national parliaments. In this respect it will be important to analyse how these institutions, one legal and one political, have already tried to operationalize the principle and which difficulties they experienced in doing so. To what extent the Early Warning Mechanism (EWS) has in fact contributed to the development of an effective and uniform interpretation will be evaluated through a case study on two recent legislative proposals. Only if a clear picture of the interpretation subsidiarity in practice is framed, it is possible to establish what can be improved and how it should be interpreted.

Lastly, based on the findings in Sections 2 and 3 an attempt will be made to propose a workable solution. Theory and practice will be combined to explain why or why not a certain theory should be adopted and to what extent one can translate this into objective criteria.

$8 \quad$ Wyatt \& Dashwood 2011, p.121. 


\section{Evolutional aspects to interpretation}

The principle of subsidiarity is derived from Roman Catholic doctrine where it related to the internal organization of the Church. ${ }^{9}$ Having in mind a common objective, it was the principles purpose to ensure that the practical steps were taken at the lower levels of organization provided that they possessed the same ability to do so, as was possessed by the higher levels..$^{10}$ It is, therefore a concept, which is concerned with conflicts of different levels and eventually found its way from the religious sphere into the national one."

Although subsidiarity was only recognized as a general principle of the Union by the Treaty of Maastricht in 1992, a slightly different form of it was already laid down in Art.5 of the Treaty establishing the European Coal and Steel Community from $1951 .^{12}$ The Community was only allowed to take direct action if this was 'absolutely necessary'. Most scholars, however, believe that the idea and fundament of subsidiarity appeared for the first time in a report on the Economic Union drawn up by the Commission in $1975 .{ }^{13}$ Indeed, it was much closer to how subsidiarity is formulated today. The report laid down that the powers of the Community should only be expanded, if the desired task could not be effectively realized by the Member States. ${ }^{14}$ After the European Single Act, although not named subsidiarity, it was closely linked to the area of environment. ${ }^{15}$

As a result of the extensive increase of Community legislation since 1984, it was finally incorporated in the Treaty of Maastricht in Art.3b of the Treaty on the European Community ${ }^{16}$ and stated ${ }^{17}$

9 Davies 2006, p.77.

10 Davies 2006, p.78.

11 Davies 2006, p.77.

12 European Parliament website on 'subsidiarity'.

13 Horspool \& Humphrey 2012, p.131.

14 Ibid.

15 Schütze 2009, p.526 The new Article $130 \mathrm{r}$ (4) EEC restricted Community environmental legislation to those actions that could "be attained better at Community level than at the level of the individual Member States"

16 An in the preamble.

17 Chalmers 2010, p.363. 
'In areas which do not fall within its exclusive competence, the Community shall take action, in accordance with the principle of subsidiarity, only if and in so far as the objectives of the proposed action cannot be sufficiently achieved by the Member States and can therefore, by reason of the scale or effects of the proposed action, be better achieved by the Community.'

Already before the Intergovernmental Conference on the Political Union, Commission President Delors had advocated the principle's use for balancing the European Community's (EC) and national powers..$^{18}$ The German Länder, predominantly (catholic) Bavaria had conducted intense lobbying beforehand since they feared in addition to the loss of competence to the German federal level, also one to the European level.19 Furthermore, Denmark and the United Kingdom were concerned about an expansion of the supranational power of the EC and demanded a safeguard. ${ }^{20}$ As a result the subsidiarity clause was incorporated into the Treaty, vaguely formulated and generally perceived to be of secondary importance. ${ }^{21}$ This changed however, when politicians employed the principle as a defence against Euro-scepticism at home and advertised it as the primary tool to protect national competences. ${ }^{22}$ It became the 'word that saved Maastricht'.23

The Commission as well as the European Council of Edinburgh in 1992 responded to the ratification crisis by elaborating on the exact content of subsidiarity. ${ }^{24}$ The Treaty of Amsterdam with its Protocol on Application of Subsidiarity and Proportionality integrated the resulting substantive and procedural guidelines clarifying the interpretation of subsidiarity. ${ }^{25}$ Three criteria where provided to check whether subsidiarity was complied with. Firstly, it was decisive whether the issue at hand contained transnational aspects that could be regulated by Member States only unsatisfactorily. Secondly, it had to be analysed whether pure Member States action or the absence of Community action would

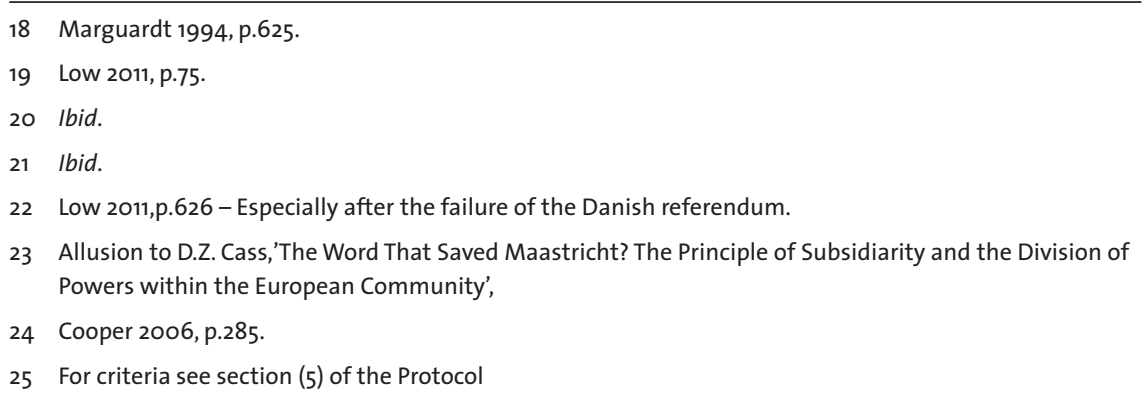


conflict with the Treaty or would significantly damage a Member States interest. ${ }^{26}$ The last criterion basically referred to the last sentence of Art.3b, as Community action had to constitute clear benefits in comparison to Member State action. These guidelines seemed to be an important step to the achievement of a uniform and workable interpretation of the subsidiarity test.

The Constitution as well as the Lisbon Treaty maintained the wording of subsidiarity since Maastricht and Art.5 (3) Treaty on the European Union (TEU) only adds explicit reference to the regional and local level. In contrast, the Working Group's proposal to include in the Article that decisions should be taken as closely as possible to the citizens was rejected. ${ }^{27}$

Protocol No.2 on Application of Subsidiarity and Proportionality attached to the Lisbon Treaty regrettably moves away from the substance of subsidiarity in its Amsterdam equivalent. It implements procedure of how national parliaments can through reasoned opinions on the compliance with subsidiarity raise a 'yellow' or 'orange card' and therefore object to a proposed legislative act by the Commission. ${ }^{28}$

To what extent this review procedure can contribute to a more comprehensive interpretation of subsidiarity will be dealt with in section 2. Although this procedure clearly entails an added value in the allocation of competences, the new Protocol would have been the opportunity (maybe even a necessity) to further develop the substantive aspect of subsidiarity.

\section{Scopes of Subsidiarity}

Especially after the Lisbon Treaty and the new role of national parliaments, subsidiarity has been subject to an enormous discussion and analyses by academia. ${ }^{29}$ Although there might be many other contributions, this paper has chosen the four most relevant approaches on how the scope of subsidiarity should be defined in a legal way. They vary from a textual interpretation to a broad concept of subsidiarity including adjacent principles, such as the principles of conferral and proportionality. ${ }^{30}$

26 Especially with the need to correct distortion of competition.

27 Working Group I, Working Document 11, p.5.

28 Art.7 Protocol No.2 - the expression 'yellow' and 'orange card' is derived from their use in soccer.

29 Martinico 2010, p.1.

30

Fabbrini \& Granat 2013, p.121. 


\subsection{Subsidiarity strictu sensu}

The first model is subsidiarity "strictu sensu" and refers to the very textual interpretation of subsidiarity. It is used by the European Commission in its Impact Assessment Guidelines from January 2009 and serves as basis for explanation of the principle in most handbooks for legal education. ${ }^{31}$ The model consist of a two-tier test has been derived from the wording of (now) Art.5 (3) TEU.

In order to analyse whether a certain legislative act is justified in accordance with the principle of subsidiarity, the first step that has to be considered is the 'sufficient attainment' ${ }^{\prime 2}$ or 'necessity test' 33 , as the Commission calls it. It is negatively formulated and asked why the objectives of an action cannot be sufficiently achieved by the Member States. Ergo, if the Member States cannot do so, the Union should act. In essence, it is examined whether legislation on a national level would overburden the Member States. ${ }^{34}$ Consequently, it requires to assess hypothetically to what extent Member States have the ability and possibility to enact a measure, yet with the restriction of the second criteria of the Amsterdam guidelines. ${ }^{35}$ Member States action alone should not lead to an infringement of the treaty, say distortion of competition.

The follow-up is the 'better attainment test' that assesses whether Union action should be preferred due to its manifest advantages. Accordingly, the Commission refers to it as a 'test of EU added value.' ${ }^{6}$ This is the case if enhanced integration can amount to such a benefit that loss of Member States competence can be outweighed. ${ }^{37}$ Furthermore, a cost-benefit analysis has to be conducted. Art 5 of Protocol No.2 requires in this respect an assessment of the financial impact as well as the presentation of qualitative and quantitative indicators that support the argument that Union can better achieve the relevant objective.

Lastly, due on an action's scale or effect the Union might better achieve it. This therefore relates to economies of scale and the reduction of disturbances due to different

31 See for example Horspool \& Humphrey.

32 Horspool \& Humphrey, p.132.

33 Impact Assessment Guidelines 2009, p.22.

34 Calliess 2010, p.18.

35 Ibid.

36 Impact Assessment Guidelines 2009, p.22.

37 Calliess 2010, p.19. 
laws..$^{8}$ The problem is however, that this is extremely centralizing as one can argue that a single standard over 27 different ones will generate economies of scale. ${ }^{39}$ Different standards always cause difficulties of coordination and alignment and from an economic perspective this results in undesirable costs. ${ }^{40}$

Thus, although under the first step possible Member States' achievements have to be considered, it is difficult to argue that they can develop for instance a harmonization measure on their own and that an EU standard would not have an added value (coordination, reduction of costs). ${ }^{41}$

This two-test is also called 'comparative efficiency' test, since it contrasts which level of government can better achieve an objective. ${ }^{42}$ It has to be conducted carefully and it presupposes that arguments in favour of national diversity are taken into account equally. However, the European institutions do not always conduct this test thoroughly and the arguments in favour of compliance are often poor. ${ }^{43}$ Due to its centralizing effect and its rather low efficiency in practice this test has proven insufficient to ensure appropriate protection of national interests. ${ }^{44}$ The next four theories on the interpretation therefore try to develop further criteria to make a subsidiarity check more effective.

\subsection{Cross-border activity test}

One way to approach this is the theory proposing a cross-border activity test. Some scholars suggest that the aforementioned subsidiarity strictu sensu interpretation should be supplemented by the requirement of 'transnational aspects' of an objective. ${ }^{45}$ This is already known from Protocol on the application of subsidiarity and proportionality attached to the Treaty of Amsterdam. Again, also the Commission in its Impact Assessment Guidelines has retained this criterion yet only as a guiding question in the context of the two-tier test. ${ }^{6}$ It essentially means that if the regulated action in question

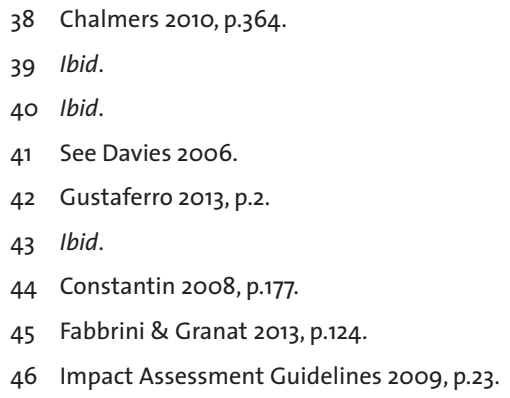


has transnational aspects that Member States cannot deal with satisfactorily, the Union should act. ${ }^{47}$ This theory even received support from parts of the ECJ.

In the Vodafone case ${ }^{48}$, Advocate General Maduro advanced to include the cross-border activity test as a criterion for review on subsidiarity compliance by the ECJ. He requested the Court to dispense from its 'light judicial approach' and dive into a more substantive analysis. For him, the 'decisive argument derives (...) from the cross-border nature of the economic activity to be regulated' 49 and if possessed the Unions has 'a special interest in protecting and promoting this economic activity.'.50 Only if this element is present the 'democratic process within the Member States is likely to lead to a failure to protect crossborder activity'.51 He reasons that the Union might be therefore not only more willing, but also more apt to legislate, as national authorities might not prioritize the issue enough or would simply take too long regulating it..$^{22}$ If the test is fulfilled, the Union's position has the advantages that all cost and benefits for the internal market are weighed against each other appropriately and satisfactorily. ${ }^{53}$ According to Maduro under a subsidiarity inquiry it was not decisive what the objective of the Community action was or the intent of the legislator behind it. It was more important to assess whether transnational aspect were present that entailed problems or increased costs if the matter was left to the MS. ${ }^{54}$ Besides the presence of these transnational aspects, he essentially requests to examine the negative and positive subsidiarity requirement separately since "better" on a European scale does not automatically translate into "insufficient" on a national level. .55

The Court did not adopt his advice, so that it cannot be expected that there will be a specification of 'transnational aspects' in the future. Although both the Court and the AG came ultimately to the same result, namely that subsidiarity was complied with,

\footnotetext{
47 Ibid.

48 C-58/08 Vodafone and Others v Secretary of State for Business, Enterprises and Regulatory Reform [2010] ECR I-4999

49 Opinion of Mr. Poiares Maduro - C-58/08 Vodafone and Others, p.5019 (para 33)

50 C-58/08 Vodafone and Others p.5020 (para 34)

51 Ibid.

52 C-58/08 Vodafone and Others p.5019 and 5020 (para 33-35)

53 C-58/o8 Vodafone and Others p.5019 (para 33)

54 Bondi et al. 2012, p.218.

55

Wortprotokoll, p.33.
} 
the intensity of inquiry differed..$^{56}$ It would constitute an additional barrier that the EU legislator has to prove for compliance with subsidiarity, thereby increasing the workability of the whole principle. The EU would be barred to act if the activity to re regulated did not extend beyond the borders of one Member State. However, in the current stage of European integration and cross-interlocking, it is rare to find an area without transnational aspects.

\subsection{Coupling with Proportionality}

Although Protocol No. 2 is dedicated to the application of subsidiarity and proportionality, national parliaments can only review subsidiarity compliance..$^{57}$ For a majority of scholars these two principles are 'sister principles' and therefore so closely linked; even overlap in some manner that a strict separation is impossible..$^{8}$ Furthermore, it seems that the decoupling was more an accident than expression of intention of the Working Group of the Constitution that was later implemented in Lisbon. ${ }^{59}$

This view is supported by the case-law of the ECJ, since in ex parte BAT ${ }^{60}$ the Court did not even go into a subsidiarity analysis, but simply referred to the part of its judgment that deals with proportionality inquiry. ${ }^{61}$ Moreover, in the aforementioned Vodafone case the two principals are treated separately, however, the core analysis is identical. ${ }^{62}$ Although it seems that Protocol No.2 does not deal with proportionality (at all), according to Art.5 the detailed statement attached to the legislative proposal should explain compliance with subsidiarity and proportionality. This indicates that both principles should be considered together to comprehensively assess when and how EU legislation should take place.

Many experts argue that a proportionality element should be part of a proper subsidiarity inquiry to secure that the powers of MS and the EU are properly balanced. ${ }^{63}$ This extension could further the consideration of national interests, meaning damages to them have to be weighed against that the added value of EU action. ${ }^{64}$

\footnotetext{
56 Craig \& De Burca 2011, p.100.

57 Art.6 Protocol No. 2 on the Application of the Principles of Subsidiarity and Proportionality

58 Weatherill 2011, p. 857 and Cooper 2006, p.283.

59 Weatherill 2011, p. 858.

6o Case C 491/o1, R v. Secretary of State ex parte BAT and Imperial Tobacco, 2002 E.C.R.I 11543.

61 Weaterhill 2011, p.857.

62 Weatherill 2011, p.858.

63 See Davies, Weatherill, Hettne \& Langdal, Constantin, Schütze.

64 Hettne \& Langdal, p.353.
} 
Weatherill, for instance, proposes a test that goes to the 'heart of subsidiarity'. The question is that 'even if the EU's objectives are advanced by and best achieved by the proposed measure, it is nevertheless important enough to override objections rooted in the worth of national diversity and autonomy?' ${ }^{65}$ The test is based on his understanding of subsidiarity as a framework for discussion on whether a shared competence should be exercised followed by the inextricable question of how it should then be exercised. ${ }^{66}$ So even if EU legislation would be of added value and more efficient, which is the most probable result if one uses subsidiarity strictu sensu only, the proportionality requirement adds that it must be so important to act that objections relating to national diversity can be outweighed.

Schütze requires understanding subsidiarity as 'federal proportionality'. ${ }^{67}$ He believes that there are two aspects of proportionality, namely a liberal and a federal one. ${ }^{68}$ The former protects private rights against disproportionate public intervention, while the latter protects the collective autonomy of people. ${ }^{69}$ If federal proportionality is incorporated in a subsidiarity test it reformulates into the question 'whether the European legislator has unnecessarily restricted the national autonomy'70

A similar test is recommended by Davies. He believes that the subsidiarity inquiry is illsuited and should be replaced by the question whether an EU measure is 'disproportionate by intruding too far into Member States values in relation to the objective' to be attained by the measure..$^{71} \mathrm{He}$ even goes a step further by saying that at this stage, proportionality is the only principle that can potentially restrict the competence creep. ${ }^{72}$ Subsidiarity, as having its roots in the Roman Catholic doctrine, has a different function. It assumes that both levels desire to achieve a common goal and the only thing it can decide is which level should do the implementing work. ${ }^{73}$ It does not deal with the question whether pursuing a certain goal is legitimate or whether there are conflicting interests or objectives, but only to whom the function should be allocated to achieve a central goal..$^{74}$ Although there is a

\footnotetext{
65 Weatherill 2011,p. 846.

66 Ibid.

67 Schütze 2009, p.533.

68 Ibid.

69 Ibid.

70 Ibid.

71 Craig \& De Burca 2011, p.10o.

72 Davies 2006, p.66.

73 Davies 2006, p.68.

74 Davies 2006, p.79.
} 
clear reason for harmonizing, for setting one uniform standard, certain desired goals, like a European high school diploma, simply go too far from a Member States perspective.75 They want to protect these competences from the Union, retain national capacity in some fields and preserve an independent legal system. ${ }^{76}$ Only when the two levels have a common goal again and Member States accept loss of competences, subsidiarity can work again in its original form - as an implementing principle. ${ }^{77}$

Until this point proportionality has to be used as a safeguard because it goes to the necessity and effectiveness of a measure..$^{7}$ Member States can only protect themselves, if they can prove that the measure disproportionately interferes with their national autonomy and interests and should be, therefore, better not be regulated at EU level.

Nevertheless in its proportionality review for EU legislative acts, the ECJ is rather reluctant. It will only annul a measure if it manifestly exceeds the Union's limits of discretion. ${ }^{79}$ The ECJ does not want to engage into an analysis of political character that requires not only the weighing of EU policies against national policies, but also a weighing within different national policies. ${ }^{80}$ For one Member States the measure might go against their culture, for another it might be of no importance at all. Therefore, the Court justifies the limited review as it wants to avoid a re-evaluation of complex economic, political or social choices. ${ }^{81}$

To conclude, coupling subsidiarity and proportionality could definitely achieve a more workable mechanism that protects national competences against disproportionate EU interference. It could develop into a real constraint on the EU legislator if it not only has to prove EU added value, but also proportionate intrusion into MS interest. Nevertheless, as exemplified by the light existing proportionality review it is not likely that the Court will adopt such a test. Therefore, in reality proportionality can also not change the picture completely.

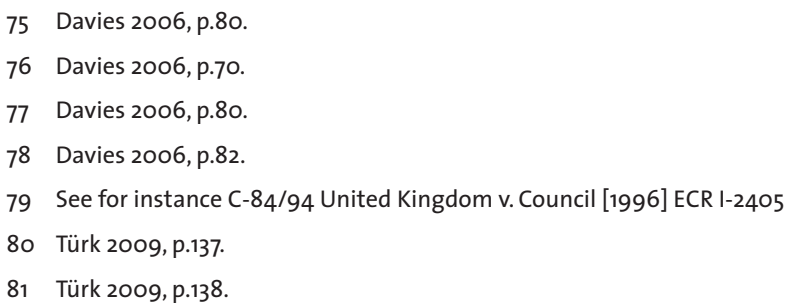




\subsection{Broad interpretation}

The theory of a broad interpretation of subsidiarity dates back to the end of the 1990 and posits that the Union principle is embodied in the whole of Art. 5 TEU. ${ }^{82}$ Representatives of this theory argue the article, incorporating the principle of conferral, subsidiarity and proportionality, works as Schrankentrias towards the exercise of Union competence. ${ }^{83}$ Predominantly German scholars discuss that a broad interpretation is necessary for an effective allocation of competences and this possible if one adapts the two other principle to subsidiarity. ${ }^{84}$ It is important to note that this interpretation has gained considerable importance since subsidiarity review by national parliaments was introduced.

Under the broad interpretation of subsidiarity, the principle of conferral is deemed to be a prerequisite that a test can be conducted in the first place. The first question to ask is whether or not the EU can act? ${ }^{85}$ It is necessary that the EU has competences to act since without, it can hardly achieve the objective in a better way than the MS. ${ }^{86}$ If there is no Union competence, a proposed action at EU level would trespass Member State competences and national parliaments, for instance, would be inclined to issue a negative subsidiarity verdict. ${ }^{87}$ An infringement of the principle of conferral is much more intrusive than what a subsidiarity check seeks to establish. ${ }^{88}$ Moreover, the German Constitutional Court expressed that the ECJ in its subsidiarity analysis incorporates the principle of conferral. ${ }^{89}$ Indeed, in its case law, as will be seen later, the ECJ first checks whether the EU had competence to act and the appropriate legal base was chosen. If not, it will not even address subsidiarity in a strict sense. $9{ }^{\circ}$

After subsidiarity strictu sensu is considered, a forth step requiring to ask how the Union should act is suggested by the broad interpretation..$^{91}$ It has to be tested whether the legislator has chosen the instruments that encroaches the least into MS' competences..$^{92}$

82 Wortprotokoll, p.4.

83 Calliess 2010, p.13 - the German word 'Schranke' means 'barrier' in English. Articles 5 TEU therefore works as a triple barrier

84 See inter alia Calliess, Kiiver (p.10)

85 Calliess 2010, p.15.

86 Kiiver 2011, p.11.

87 lbid.

88 Prof. Lorz in Wortprotokoll, p.9.

89 Prof. Puttler in Wortprotokoll, p.13.

90 See for instance Tobacco Advertising

91 Calliess 2010, p.20.

92 Ibid. 
While it might be legitimate according to subsidiarity to enact an EU recommendation due the better overview about the divergent laws of Member States, this does not hold true for every type of EU action. ${ }^{33}$ The Commission itself notes in its Green Paper on policy options for progress towards a European Contract Law ${ }^{94}$ that option 7 proposing a Regulation for a European Civil Code could raise serious subsidiarity issues. ${ }^{95}$ When it comes to total harmonization, there might not be 'enough' subsidiarity to justify Union action..$^{96}$

This last tier of the test might, however, only be very clear as regards instruments at the on the other side of the spectrum. A recommendation is rather easy to justify, whereas for a regulation subsidiarity can be a real barrier. The answer is, however, not as straightforward between a Directive and a Regulation providing for an optional instrument. 97

In the context of the last step of the test there might arise difficulties to hierarchize. Nevertheless, much will depend on the type of objective and the exact content. One has to consider the broad interpretation as a whole, and from this perspective the two additional steps can really work against the centralizing tendency of a pure textual interpretation.

Other authors, however, fiercely militate against this extensive interpretation. They believe that the debates in and around the Working Group on Subsidiarity have shown that the three principles need to be separated. ${ }^{8}$ Furthermore, they criticize the Court's mixing of principles. Statements such as 'subsidiarity and proportionality; It's all the same' by ECJ President Skouris should be clearly avoided. .99

93 Kiiver 2011, p.12.

$94 \operatorname{COM}(2010) 348$ final Green Paper from the Commission on policy options for progress towards a European Contract Law for consumers and businesses.

$\operatorname{COM}(2010) 348$, p.11.

Kiiver 2011, p.12.

97

Of course a Directive is only binding as to the achievement of an objective and the means of implementation is left to the Member States whereas an optional instrument leaves (formally) national laws untouched and directly puts in place a second regime that can be chosen voluntarily. For which one is there now enough subsidiarity? Both are not as strict as a regulation, yet also not merely a recommendation. They both heavily affect the exiting national law. The Directive does so by altering the national in order to comply with an objective, while the Optional Instrument puts national law in competition with an EU instrument. Although at first sight, this is softer than a Directive, in the long run, however, it can lead to an alignment of national and EU law or to the fact that EU law is preferred over national law so that national law loses its effect

98 Fabbrini \& Granat 2013, p.122.

Calliess in Wortprotokoll p.49. 
The most convincing argument why a broad interpretation is necessary is that ECJ's review is with respect to the legality of a measure is working well, whereas in respect to proportionality and foremost subsidiarity the ECJ leaves a wide discretion to the EU legislation not wanting to substitute its own opinion. Therefore, it would be illogical so solely focus on subsidiarity strictu sensu since the ECJ seems to avoid a deeper analysis of it. ${ }^{100}$ This will, however, be considered to a greater extent in the next section.

\section{Review by the European Court of Justice}

Although subsidiarity has been frequently invoked before the Court of Justice, it has never annulled a measure on the ground that subsidiarity was breached. ${ }^{101}$ The word frequently has to be, however, specified. Since its introduction by the Treaty of Maastricht, there were 20 challenges of subsidiarity compliance in total..$^{102}$ Only half of them were real subsidiarity challenges, whereby the rest lacked sufficient evidence by Member States or mistakenly related to an exclusive competence. ${ }^{103}$

These rather few challenges can be based on the fact that before the Treaty of Amsterdam unanimity was the main voting procedure in the Council. ${ }^{104}$ If a Member State believed that a measure could be sufficiently dealt with at national level, it could simply block a measure. ${ }^{105}$ Consequently, consensus had to be found rendering subsidiarity challenges afterwards rare. Only with the increased use of Qualified Majority Voting in the Council and increased parliamentary involvement in the legislative process changed the picture to some extent. Member States could be outvoted even if they were fiercely against the proposal. ${ }^{106}$

However, if on examines the few existing cases where subsidiarity was reviewed by the Court it did so rather in light-touch manner without looking below the surface. ${ }^{107}$ Some authors even claim that the Court is unwilling to review violations of subsidiarity. ${ }^{108}$

\footnotetext{
100 Calliess in Wortprotokoll, p.50.

101 Chalmers 2010, p.364.

102 Craig \& De Burca 2011, p.99.

103 lbid.

104 Weatherill 2010, p.61.

105 lbid.

106 lbid.

107 Wyatt \& Dashwood 2010, p.117.

108 Estella 2002, p.102.
} 
Others question whether or not the principle is justiciable in the first place, meaning whether the Court has capacity to enforce respect for it. ${ }^{109}$ As Lord Mackenzie Stuart ${ }^{10}$ has formulated it 'the interpretation of subsidiarity is a political issue and not one for the Court of Justice'."' In essence, a subsidiarity analysis requires the Court to pursue political considerations if it assesses on which level an action would be more effective or where it can be better attained. ${ }^{12}$

Furthermore, subsidiarity is sometimes considered to be of a subjective character, it is a policy choice that should be made by the political institutions which are democratically accountable.113 Therefore the ECJ usually grants the legislator a wide margin of discretion and will only annul a measure if there has been a manifest error of appraisal. ${ }^{14}$ The Court seems to be reluctant to replace this political choice with its own one, if it for instance would strike the balance differently and all legislative bodies had approved the measure during the legislative process. ${ }^{115}$

Another factor which constrains the ECJ's review is that it can only review ex post meaning after the legislative act has entered into force and formed part of acquis communautaire. ${ }^{116} \mathrm{As}$ an annulment would result in considerable uncertainties, the Court is reluctant to take a detailed look at the arguments against subsidiarity compliance. A solution to tackle this problem proposed by the Working Group on subsidiarity was the introduction of an opinion of the ECJ on subsidiarity compliance, comparable to the French Constitutional Council. ${ }^{17}$ This was, however, not adopted in the Lisbon Treaty.

\subsection{The development of subsidiarity review - a success?}

Nevertheless, the case law shows that the Court has grown into its role over time and developed its review. Earlier case law from 1994 exemplifies the Court's reluctant approach

\footnotetext{
109 Wyatt \& Dashwood 2011, p.117 - This has however been rejected since the Court has accepted to review subsidiarity.

110 Former President of the Court of Justice (1984-88).

111 Emiliou 1994, p.77.

112 Emiliou 1994, p.78.

113 Ibid.

114 Working Group I, Working Document 11, p.7.

115 Chalmers 2010, p.364.

116 Working Group I Working Document 11, p.7.

117 Working Group I Working Document 11, p.9.
} 
in both procedural and substantive terms. ${ }^{118}$ The former was dealt with in Germany $v$ EP and Council'19 where the Court held that an 'express reference' to subsidiarity compliance was irrelevant with regard to the validity of the measure. ${ }^{120}$ It was sufficient if the recitals demonstrated the Union's added value. ${ }^{121}$ A famous example for the 'light' substantive review is the Working Time Directive ${ }^{122}$ case in which the UK alleged subsidiarity infringement, since the benefits of action at EU level were not apparent. ${ }^{123}$ The Court held that since the Union had competence to harmonize in the area of health and the Council found it necessary to improve protection, action at Union level was per se justified. ${ }^{124}$ This generated the impression that whenever the Union had competence it was automatically in a better position to legislate, although Art.5 (3) clearly states otherwise.

In the following years, the Court gained more confidence in its review. In the Biotechnological Inventions ${ }^{125}$ case, the Court reasoned on the basis of the EU's advantageous position in terms of the action's scale or effect. ${ }^{226}$ The Directive ensured the functioning of the internal market by removing divergences between Member States' laws. This harmonizing effect could not be achieved by Member States action alone, but by the Union as the scale and effect of the proposed action could better regulate the consequences on trade. ${ }^{27}$

Only in ex parte $B A T^{128}$ the Court clarified that the principle of subsidiarity applied to Art.114 TFEU. The substantive review of subsidiarity is, however, essentially the same as above. ${ }^{129}$ Subsidiarity was satisfied as the Directive's objective was to eliminate barriers resulting from regulatory differences among Member States. This could not be sufficiently achieved by Member States and therefore better achieved at Union level. Despite the Court's progressing engagement in the substantive review, its reasoning is identical in all cases and

\footnotetext{
118 Craig \& De Burca 2011, p.98.

119 C-233/94 Germany v. Parliament and Council [1997] ECR I-2405

120 Craig \& De Burca 2011, p.98.

121 Ibid.

122 C-84/94 United Kingdom v. Council [1996] ECR I-5755

123 Craig \& De Burca 2011, p.98.

124 lbid.

125 C-377/98 Netherlands v. Parliament and Council [2001] ECR I-7079

126 Craig \& De Burca 2011, p.98.

127 C-377/98 Netherlands v. Parliament and Council, para 31

128 C-491/o1 Queen v. Secetary of State for Health, ex parte British American Tobacco (Inv.) Ltd \& Imperial Tobacco Ltd. [2002] ECR I-11453

129 Weatherill 2011, p.843.
} 
establishes compliance with subsidiarity whenever common rules are set by the EU. ${ }^{130}$ Put differently it 'is left searching in vain to imagine any circumstances in which the adoption of common rules at EU level fall foul of the Court's test'. ${ }^{131}$

Even in the aforementioned Vodafone case in which AG Maduro demanded a justification as to why Union action was necessary under the subsidiarity inquiry, the Court simply decided that this was clear from the preamble. ${ }^{132}$ Even if true, such reasoning is only superficial and clearly not satisfactory. ${ }^{33}$

The Court's sole inquiry seems to be whether not the reasons presented by the legislator make sense. ${ }^{134}$ One has the impression, that through the Court's restrictive interpretation of subsidiarity its influence as a legal principle in terms of review has only been marginal. ${ }^{135}$

\subsection{The relevance of Tobacco Advertising}

Arguably however, the Court's core subsidiarity test has matured in the context of the use of Art.114 TFEU as a legal base for Union legislation. ${ }^{136}$ It is a hidden scrutiny that the Court conducts by reviewing the legality of Union legislation against the principle of conferral in Art.5 (2) TEU. ${ }^{137}$ This de facto review of subsidiarity is exemplified by the landmark case Tobacco Advertising ${ }^{138}$ in which the German government sought annulment of Directive 98/43/EC dealing with the approximation of Member States' laws in the field of advertisement of tobacco products. Under the heading of the legal base, the German government argued in paragraph 13 that the concerned advertising was 'essentially an activity whose effects [did] not extend beyond the borders of individual Member States'. It was a matter of purely national concern and could consequently sufficiently be regulated at national level. This relates to the sufficient attainment test under the first sentences of Art.5 (3) TEU. ${ }^{39}$

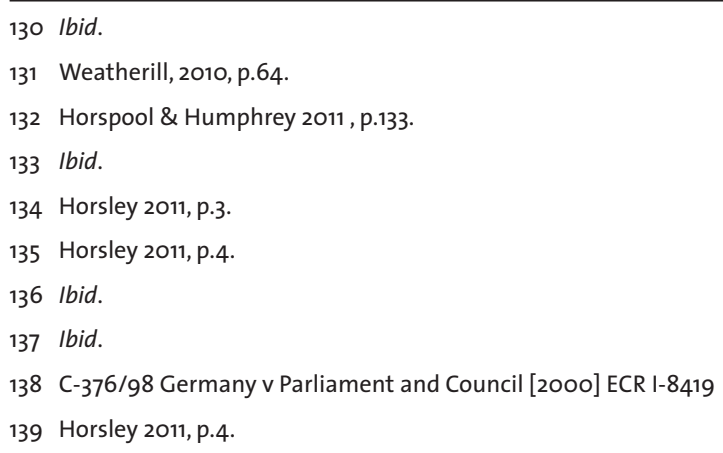


While the Court recognized that Art. 114 TFEU was indeed the correct legal base for approximating national laws in order to ensure the establishment and functioning of the internal market, it also gave instructions referring to whether that competence should be exercised. ${ }^{140}$ This latter analysis clearly falls within the scope of subsidiarity. ${ }^{141}$ The Court held that the Union does not have a general power to legislate with respect to the internal market and that it was insufficient to merely find differences between national laws. ${ }^{142}$ There had to be more than an abstract risk that these differences could become a barrier to the exercise of the fundamental freedoms. ${ }^{143}$

When the Court then applied this to the Directive in question, it found that especially in relation to static media, such as ashtrays or cinema advertisement, the measure was not able to add any value since it did not help to increase trade in the products targeted. ${ }^{144}$ There were no real obstacles to the free movement of these products and therefore Union action was unjustified. Essential is, however, that the Court applied the better attainment test in the second sentence of Art.5 (3) TEU. ${ }^{145}$ The Directive could not improve the functioning of the internal market and the Union had therefore exceeded its competence under Art.114 TFEU.

Two years later in the ex parte $B A T^{146}$ case the same reasoning was brought under the subsidiarity umbrella by the Court. The Court expressly referred its reasoning in Tobacco Advertising by stating that the Union legislator did not have an exclusive competence to regulate the internal market, but that the exercise of competence was limited to actions seeking to advance the functioning of the internal market. ${ }^{147}$ This should be done either by eliminating barriers to the free movement or by removing distortions of competition. ${ }^{148}$ The actual reasoning, as mentioned above, if this new requirement was complied with is, however, again very short and superficial. ${ }^{149}$

\footnotetext{
140 lbid.

141 Ibid.

142 C-376/98 Germany v Parliament and Council, para. 83 \& 84

143 lbid.

144 Horsley 2011, p.5.

145 lbid.

146 C-491/01 British American Tobacco (Investsments) and Imperial Tobacco Ltd. [2002] ECR I-11453

147 C-491/01 British American Tobacco (Investsments) and Imperial Tobacco Ltd., para 179

148 lbid.

149 C-491/o1 British American Tobacco (Investsments) and Imperial Tobacco Ltd., para 182 \& 183
} 
Subsidiarity review in the context of Art.114 TFEU therefore seems to render the exercise of competence conditional upon the presence or prospective emergence of negative externalities arising through different national laws. ${ }^{150}$

In contrast to the interpretation of subsidiarity in the above mentioned case law, the two latter cases seem to indicate that the Court uses the subsidiarity strictu sensu coupled with the cross-border-activity test. The Court links this to the principle of conferral in the sense that the Union should exercise its competence under Art.114 TFEU only if there is a 'collective action problem'. ${ }^{51}$ There has to be a transnational aspect to the problem that Member States cannot satisfactorily regulate on their own. Subsidiarity is, consequently, legally operationalized by assessing whether obstacles to trade and distortion of competition are present and if so, also to a considerable extent as to justifying intervention on a Union level. ${ }^{152}$ In contrast, if this is not the case there is no collective action problem. As illustrated by Tobacco Advertising, in terms of static media there was almost no intraUnion trade, due to the fact that advertising was adapted to each national market. ${ }^{153}$ Divergent laws did therefore not entail obstacles to trade or distortion of competition and by nevertheless regulating this on a Union level, the legislator acted ultra vires and violated subsidiarity due to the missing collective action problem. The Union does, therefore, not possess a 'carte blanche' to harmonize laws as it wishes. ${ }^{154}$

\subsection{The Court's interpretation}

Despite the progress in Tobacco Advertising, in later cases where the excess of power under Art.114 TFEU was at issue such as Swedish Match ${ }^{155}$ the Court assessed subsidiarity neither under the legal base section nor as a separate plea. ${ }^{156}$

Even worse, the legislator has recognized this lack of interpretation and intensity of review as well and formulates the justification as regards subsidiarity compliance in preambles uniformly. As Weatherill phrases it, the Court's reasoning has become a 'drafting guide'.157 If one, for instances, compares recital 21 of Regulation 1007/2009 on seal

\footnotetext{
150 Horsley 2011, p.5.

151 Kumm 2006, p.531.

152 lbid.

153 Tobacco Advertising, para 15 \& 99

154 Weatherill 2010, p.65.

155 V-210/03 Swedish Match [2004] ECR I-11893

156 Weatherill 2010, p.65.

157 Weatherill 2011, p.845.
} 
products and recital 36 of Proposal for a Regulation on a Common European Sales Law, a mere repetition can be discovered. Both state that subsidiarity is complied with 'since the objective of this Regulation, namely the elimination of obstacles to the functioning of the internal market by (...), cannot be sufficiently achieved by Member States and can therefore be better achieved at Union level'. The recitals seem to implement exactly the Court's reasoning in Tobacco Advertising, yet with the knowledge that subsidiarity is no threat for annulment unless the Union regulates (manifest) non-transnational aspects.

Interesting is, however, how the Court will position itself where the legal base is not Art.114 TFEU but one for an environmental or social policy measure. ${ }^{158}$ Here it will become impossible for the Court to interpret subsidiarity in light of the principle of conferral, since the validity of the choice of legal base is not dependent on a collective action problem that necessitates harmonization. ${ }^{159}$

The initial problem will reoccur where the Court has to weigh economic, social and cultural arguments for or against centralization. ${ }^{160}$ It will afford the legislator with a wide discretion and only in extreme circumstances annul on grounds of subsidiarity. ${ }^{61}$

The only indication we have so far is Opinion $2 / 94^{162}$ on the accession of the Community to the European Convention on Human Rights (ECHR). ${ }^{163}$ The Finish government argued that the scope of Art.235 EC (now 352 TFEU $^{164}$ ) was restricted by the principle of subsidiarity. ${ }^{165}$ Although the Court did not directly address subsidiarity, it held that the Community did not have the competence to accede to the ECHR under Art.235 EC since a decision of such constitutional significance could only be taken via a Treaty amendment meaning on a political level by the Member States. ${ }^{166}$ The reasoning of the Court, therefore, neither denied

\footnotetext{
158 Wyatt \& Dashwood 2011, p.119.

159 lbid.

160 Chalmers 2010, p.376.

161 lbid.

162 Opinion 2/94 on Accession by the Community to the ECHR [1996] ECR I-1759

163 De Burca 1998, p.225

164 Treaty on the Functioning of the European Union (TFEU)

$165 \mathrm{lbid}$. Art.352 TFEU states that If action by the Union should prove necessary, within the framework of the policies defined in the Treaties, to attain one of the objectives set out in the Treaties, and the Treaties have not provided the necessary powers, the Council, acting unanimously on a proposal from the Commission and after obtaining the consent of the European Parliament, shall adopt the appropriate measures.(...) the European Parliament.
}

166 Opinion 2/94 para 34 \& 35, see also: De Burca 2011, p.225-226. 
competence on the basis that the accession fell outside the scope of the Treaty nor that Art.235 EC could not include the objective of respect for human rights, rather a subsidiarity argument was decisive. ${ }^{167}$ The issue was of such sensitivity that it was more democratic to decide it on a national level than on the EU one. ${ }^{168}$ Nevertheless, this underlines the previous arguments that the Court firstly avoids a subsidiarity analysis and secondly that it will only intervene in extreme circumstances, such as the accession to the ECHR.

Due to the lack of an effective interpretation of subsidiarity, it has not yet become a principle meaning a rule of constitutional value that renders the limits of Union actions reviewable. ${ }^{169}$ A solution could be to focus on the procedural aspects of subsidiarity, so that the Court will assess whether or not the legislative institutions have justified subsidiarity compliance properly. ${ }^{70}$ This would then link subsidiarity to annulment on the basis of the infringement of an essential procedural requirement. The Commission already provides qualitative and quantitative data in its Impact Assessment, but if the data and reasons are only formal or sparse the Court could reasonably conclude that subsidiarity has not been adhered to. ${ }^{171}$

\section{Review by national parliaments}

In order to compensate for the difficulties of judicial review, several institutional innovations were proposed. ${ }^{172}$ Weiler for instance, suggested establishing a European Constitutional Court, consisting of the President of the Court of Justice and the judges of the Member States' constitutional courts. ${ }^{173}$ These senior judges could possibly be more confident to control and set limits of Union powers. Another proposal by Leon Brittan ${ }^{174}$ sought to create a chamber of national parliamentarians who were charged with the

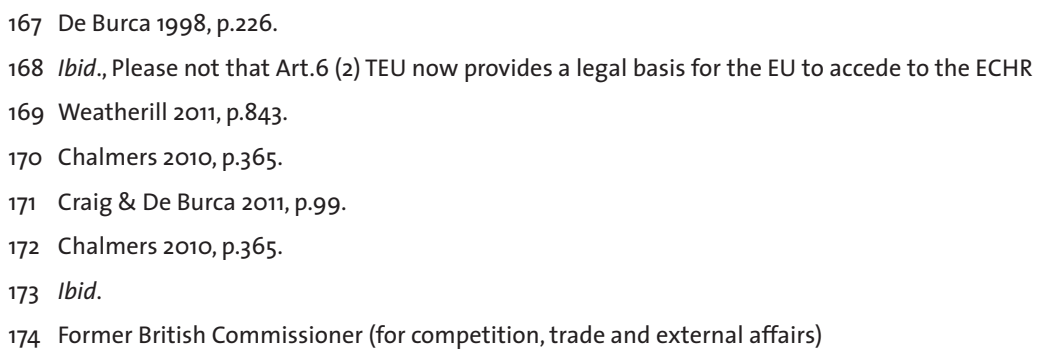


duty to review subsidiarity compliance. ${ }^{75}$ The latter idea served as an inspiration for the Early Warning Mechanism (EWS) introduced by Lisbon in Protocol No.2 on the Application of Subsidiarity and Proportionality. ${ }^{176}$

The Working Group on Subsidiarity of the European Convention discussed several possibility on how to enhance subsidiarity control, but came ultimately to the conclusion that subsidiarity is 'a principle of an essentially political nature' which was best monitored by political institutions. ${ }^{177}$ National parliaments (NP), being at the frontier of competence, were considered to be most suitable to guard as 'subsidiarity watchdogs' over compliance. ${ }^{178}$ If a certain matter is regulated at EU level, NP are the ones who lose their decision-making power over it and might be the most sensitive in case the principle is infringed. ${ }^{79}$

The solution to the democratic deficit and a weak subsidiarity principle, was an ex ante review of subsidiarity compliance by NP that could make the principle more effective by providing a political input beforehand as to avoid the hardships of ex post judicial review. ${ }^{180}$

The review procedure can be summarized as follows. Under Art.4 Protocol No.2 the Commission, or in case the proposal originates from another institution, the Council or the European Parliament have to forward draft proposal to national parliaments and need to justify in a detailed statement as to why the measure complies with the principles of subsidiarity and proportionality. ${ }^{181}$ National parliaments can then review (only) subsidiarity compliance and issue a reasoned opinion within eight weeks if they find a breach of the principle. ${ }^{182}$ A so called 'yellow card' is raised if the reasoned opinion represent one third $(18 / 54)$ of the votes allocated to national parliaments. ${ }^{183}$ It requires the Commission or one of the other institutions to review its proposal. It can decide to maintain, amend or withdrawal the proposal, but has to give reasons for its choice. ${ }^{184}$

175 Chalmers 2010, p.365.

176 Chalmers 2010, p.365.

177 CONV 286/o2, p.2 - Cooper 2006 (p.291) lists several options that were considered by the Working Group. Member discussed the possibility of having an ad hoc body that monitors the application of subsidiarity, a special Commissioner for subsidiarity or an ex ante review by the ECJ.

178 Cooper 2006, p.293.

179 Dashwood 2004, p.68.

180 Wyatt \& Dashwood 2011, p.121.

181 Art.5 Protocol No.2 on the Application of the Principles of Subsidiarity and Proportionality

182 Art.6 Protocol No.2

183 Art.7 (1) Protocol No.2, each parliament has two votes; in case the parliament is bicameral, each chamber has one vote

184 Art.7 (2) Protocol No.2 
In the course of the ordinary legislative procedure it is possible to raise an 'orange card'. This is the case if the reasoned opinions represent a simple majority of allocated votes (28/54). ${ }^{185}$ The proposal must be also reviewed by the Commission, but if it decides to maintain it the European Parliament and the Council will have to vote on subsidiarity compliance. ${ }^{186}$ The proposal must be withdrawn if a majority of $55 \%$ in the Council or a simple majority of the European Parliament consider that the subsidiarity principle has not been observed. ${ }^{187}$

Thus, there will be an early warning that a legislative proposal will face opposition. It is, however, also nothing more than a warning. National parliament cannot veto a proposal or suggest amendments. ${ }^{188}$ It was feared that NP would not engage in a constructive dialogue with the European Institutions if they had the power to veto legislative proposals anyway. ${ }^{189}$ The political effect of a 'yellow card' should, however, not be underestimated. ${ }^{190}$

This part of the paper will inquire to what extent parliaments' interpretation of subsidiarity in their reasoned opinion has contributed the operationalization of the principle. It is important to assess how they define the scope of subsidiarity and if this can ensure an effective divide between Member States' and EU competences. Keeping in mind that under Art.8 Protocol No.2 a Member State can bring an action for annulment on grounds of subsidiarity on behalf of its national parliament, the Court could be presented with a 'wealth of material [and] argumentation' originating from the parliaments' reasoned opinion so that 'subsidiarity could metamorphose from a politically subjective into a readily justiciable principle'. ${ }^{191}$

\subsection{Case study on subsidiarity interpretation}

In order to assess how NP interpret subsidiarity two legislative proposals have been chosen, namely the Proposal for a Council Regulation on a Common European Sales Law (CESL) and the Proposal for a Council Regulation on the right to take collective action within the context of the freedom of establishment and the freedom to provide services,

\footnotetext{
185 Art.7 (3) Protocol No.2

186 Art.7 (3) (a) \& (b) Protocol No.2

187 lbid.

188 Cooper 2012, p.451.- The drafters of the Protocol did not want to award NP a co-legislative function in order to avoid complexity and delay in European decision-making

189 Cooper 2006, p.294.

190 Prof.Wurmeling in Wortpotokoll 2010, p.21.

191 Wyatt \& Dashwood 2011, p.123.
} 
better known as Monti II Regulation. ${ }^{192}$ Both of them touch upon very sensitive issues, namely contract and social rights law and therefore serve as good examples to assess parliaments' interpretation. Especially in these cases it will be interesting to see how NP have tried to defend their 'territory'.

Against the CESL only four reasoned opinion were issued, whereas the Monti II Regulation was subject to the first 'yellow card' ever raised since its introduction in 2009. $12 \mathrm{NP}$, (seven unicameral and five bicameral) amounting to 19 out of 54 votes, found the proposal to be in violation of the principle of subsidiarity. On $12^{\text {th }}$ September 2012 the Commission withdrew its proposal, yet denying that it had breached subsidiarity since NP had mostly expressed concerns relating to the legal base, the competence of the EU to legislate and compliance with the principle of proportionality. ${ }^{193}$

Firstly, a general overview about the interpretation of subsidiarity in the reasoned opinions issued against CESL and Monti II will be provided. In this regard, the tables contained in Annex I of this paper will be discussed. The above described four theories have been translated into six criteria that each reasoned opinion was checked against. It was first necessary to examine whether subsidiarity was mentioned in the first place. The next step was to analyse to what extent NP used arguments relating to the comparative efficiency test and whether or not they looked at both elements of it. Lastly, it was assessed if NP considered the principle of conferral and proportionality or found transnational aspects to a regulatory problem relevant.

Secondly, a closer look will be taken at those NP which seem to have operationalized the principle already. The solutions of the German Bundestag, the Belgian Sénat, the House of Commons as well as the Dutch Tweede Kamer will be presented.

\subsubsection{Findings}

All NP have mentioned subsidiarity in their reasoned opinions. However it becomes clear from the table that a strict test of subsidiarity is much less pronounced in the discussion of Monti II, being adopted by less than $50 \%$ of all NP. The analysis also shows that generally the reasoned opinions contain only one to two sentences on the strict test. Another potentially confusing result is that only five parliaments apply the sufficient attainment

$192 \operatorname{COM}(2011) 635$ final - Proposal for Regulation of the European Parliament and of the Council on a Common European Sales Law \& COM (2012)13 final - Proposal for a Council Regulation on the right to take collective action within the context of the freedom of establishment and the freedom to provide services

$193 \operatorname{Ares}(2012) 1058907$ 
test while six parliaments look for added value in the EU. Overall five NP do not even consider the comparative efficiency test. Assessing the validity of the legal base and the compliance with the principle of proportionality enjoy much greater support with more than $80 \%$ of all NP applying these measures. Only the Finnish Eduskunta and the British House of Commons include transnational aspects in their subsidiarity analysis, with the reasoned opinion of the House of Commons stating that transnational aspects will be tested and then fully omitting any further discussion on the matter let alone a test.

Looking at the analysis for CESL a similar pattern as described above can be observed. It becomes much clearer that parliaments concentrate on the second aspect of subsidiarity strictu sensu than on the first aspect, with none of the parliaments applying the latter while all of them apply the former measure. $75 \%$ of all NPs assess whether or not proportionality was adequately observed by the legislator and criticize the choice of legal base. As with Monti II only the House of Commons names the relevance of transnational aspects for a subsidiarity test but then does not further mention or apply the concept in their reasoned opinion.

Lastly, it is important to note that the Polish Senat found no breach of subsidiarity in Monti II, but rather a breach of the principle of proportionality. The same goes for the Bulgarian National Assembly in their evaluation of the CESL. These were not counted towards the threshold.

\subsubsection{Approach of selected national parliaments}

The table in Annex I as well as the findings above show that NP approach subsidiarity in a different way, using different criteria to assess compliance. A closer look will now be taken at the subsidiarity test in the German Bundestag, the Belgian Sénat, the UK House of Commons and the Dutch Tweede Kamer.

As regards the German Bundestag, the reasoned opinion on CESL provides information on how Bundestag interprets subsidiarity. It states that the criteria national parliaments should apply in the subsidiarity check must be understood 'comprehensive in their scope'. ${ }^{94}$ It covers the choice of legal base, subsidiarity in the strict sense and compliance

194 Reasoned Opinion German Bundestag, p.2. 
with the principle of proportionality. ${ }^{195}$ Therefore, a three part test is applied under which the parliament first determines whether or not the EU was competent to act and has observed the principle of conferral. ${ }^{196}$ Afterwards compliance with subsidiarity will be assessed. Furthermore, the Bundestag argues that undertaking a subsidiarity analysis in isolation of proportionality would be pointless, as provisions on competence usually clarify both the scope of subsidiarity and proportionality. ${ }^{197}$ To confirm its broad interpretation, an extensive list of legal literature is presented and reference is made to the round table discussion by the Bundetag's Subcommitteee on European Law on the 'Assessment of the subsidiarity principle provided for in EU Law' in 2010. ${ }^{198}$

During this discussion, leading experts such as Prof. Dr. Calliess or Dr. Wuermeling member of the Working Group on Subsidiarity expressed their opinion on which criteria the Bundestag should use. The test, which was finally adopted, is essentially based on Prof. Calliess' proposal in his PhD on the principles of subsidiarity and solidarity in the EU. ${ }^{199}$ It includes three questions that should be asked in the context of the subsidiarity check, namely can the EU act, whether it should act and if so how. ${ }^{200}$ Calliess is, therefore, a representative of the broad interpretation theory described above. However, also the other experts invited advised the Bundestag to include all three elements of Art. 5 TEU in their reasoned opinions, even include purely political aspects. ${ }^{201}$ Prof. Lorz motivates this by describing subsidiarity as a hybrid with a political and a legal dimension. ${ }^{202}$ In contrast to a clear cut legal subsidiarity analysis that actions at the ECJ should address, the scope of parliaments' reasoned opinions should be more liberal and broad. ${ }^{203}$ In the long run, this could force the ECJ to decide on the delimitation between the principles laid down in Art.5 TEU and thereby on how subsidiarity should be interpreted by the NP. ${ }^{204}$ The reasoned opinion on the CESL reflects this approach quite well. The Bundestag examines in detail why the choice of legal base was incorrect and the goes into compliance with subsidiarity

\footnotetext{
195 lbid.

196 Ibid.

197 lbid.

198 Reasoned Opinion German Bundestag , p.3.

199 Christian Calliess „Susbsidiaritäts- und Solidaritsprinzip in der EU“ 2nd edition 1999

200 Calliess 2010, p.15.

201 Lorz in Wortprotokoll 2010, p.7 and Puttler in Wortprotokoll 2010, p.13.

202 Lorz in Wortprotokoll 2010, p.7.

203 lbid.

204 Lorz in Wortprotokoll 2010, p.9.
} 
and proportionality. ${ }^{205}$ It is important to note that it mixes subsidiarity and proportionality, since it first starts quickly with the EU added value test and then states reasons as to why the proposal is disproportionate. ${ }^{206}$

The Belgian Sénat seems to have adopted a similar interpretation, yet under different headings. In its reasoned opinion on the CESL section 3 is devoted to methodological considerations. It clarifies that in monitoring compliance legal as well as political assessment criteria will be used. ${ }^{207}$ Moreover, it has established three questions that examined by Senate in order to examine subsidiarity. ${ }^{208}$ Firstly, there is the issue of power in the context of which it will be analysed whether or not the EU has exceeded the limits of its powers and the legal base selected can indeed authorize them to act in this chosen field. Secondly, under the issue of relevance the Senate addresses what is essentially a proportionality test. Thirdly, the issue of closeness is considered where it is asked if the proposal has sufficiently respected initiatives and actions of national authorities and then the two aspects of subsidiarity strictu sensu are applied.

The UK House of Commons is under the top five most participative NP. ${ }^{209}$ It has issued a reasoned opinion against the CESL and Monti II and seems to follow a clear structure on how subsidiarity compliance should be assessed. The first part of each reasoned opinions explains the procedural requirements under Art.5 Protocol No.2 the initiating institution, mostly the Commission, has to comply with. ${ }^{210}$ Subsequently, reference is made to the guidelines on the application of subsidiarity attached to the Treaty of Amsterdam, including the requirement of the presence of transnational aspects. ${ }^{211}$

When the House of Commons then applies this to the proposal in question a different line of reasoning is, however, applied. In both cases it claims that the Commission has infringed an essential procedural requirement by failing to prove in its detailed statement

205 Reasoned Opinion Bundestag CESL p. 4-6.

206 lbid.

207 Reasoned Opinion Belgian Sénat CESL, p.3.

208 Reasoned Opinion Belgian Sénat CESL p. 3-4 describes the whole test mentioned below

209 Paulo 2012, p.7.

210 Reasoned Opinion House of Commons CESL, p.1 \& Reasoned Opinion Monti II, p.1.

211 Resoned Opinion House of Commons CESL, p.2 \& Reasoned Opinion Monti II, p.2. 
why action at EU level has clear benefits and is necessary. ${ }^{212}$ In its reasoned opinion the on the CESL an additional paragraph is dedicated to the compliance with subsidiarity itself, whereby it is argued that the proposal is neither necessary to improve trade nor can produce clear benefits as for instance legal complexity and uncertainty is furthered by the proposal. ${ }^{213}$ While the latter argumentation clearly accords to the EU added value test under subsidiarity in the strict sense, the former is an element of proportionality. The House of Commons does not prove whether or not the Member States could sufficiently achieve the objective of the proposal itself, but rather whether the measure is necessary to achieve its aim, in this case encouraging cross-border trade. ${ }^{214}$ In both reasoned opinions the principle of conferral is not assessed.

Overall, it seems that the House of Commons tries to argue as close as possible under the heading of subsidiarity strictu sensu. Lastly, it has to be mentioned that also the House of Commons has asked experts which criteria it should use to assess compliance with the principle of subsidiarity. In the European Scrutiny Committee's Report, Professor Dashwood and Professor Hix have denied that subsidiarity is 'capable of objective assessment'.215 The heterogeneous preferences of Member States could not be addressed by purely legal subsidiarity criteria, but the question of which level should act was ultimately a political one. ${ }^{216}$ Nevertheless, the House of Commons seems to have decided for the use of objective criteria. The interpretation of subsidiarity in Dutch Tweede Kamer will serve as a last example. The EU Advisory Committee interprets subsidiarity in line with the comparative efficiency test and the guidelines proposed by Protocol attached to the Treaty of Amsterdam. ${ }^{217}$ It advises parliamentarians to observe these requirements in their argumentation. This could be described as a checklist. Indeed, the Tweede Kamer's reasoned opinion on Monti II criticizes that proposed measure would not entail any added value and is already regulated sufficiently and satisfactory in national legislation. ${ }^{218}$ However, in the last section the choice of legal base is addressed and on enquiry the Committee states that the check of competence is essentially the first step they conduct in the context of the subsidiarity

\footnotetext{
212 Reasoned Opinion House of Commons CESL pp.5-6. \& Reasoned Opinion Monti II p.5-6.

213 Reasoned Opinion House of Commons CESL, p.7.

214 Reasoned Opinion House of Commons CESL, p.8.

215 House of Commons, 33rd Report, p.5.

216 lbid.

217 Interview with Mrs. Janneke Timmers - Annex II.

218 Reasoned Opinion Tweede Kamer Monti II (courtesy translation), p.1.
} 
test. ${ }^{219}$ Moreover, a representative from the Committee underlines that although parliamentarians are well aware that they should only argue legally, they are part of a political institution and therefore tend to address political aspects. ${ }^{220}$ She says that the subsidiarity check, regardless of the initial interpretation, boils down to an expression of the parliament that it wants or does not want a legal instrument. ${ }^{221}$ Therefore political arguments will find its way into the reasoned opinion, as well. Nevertheless, from a purely legal perspective, the Tweede Kamer, desires to extent the EWS also towards a proportionality check. ${ }^{222}$ Although, a proportionality assessment sometimes occurs in a reasoned opinion it is strictly not seen as part of the test itself. ${ }^{223}$ If concerns are raised they are usually attached to the reasoned opinion but in a separate paragraph than the strict subsidiarity analysis. ${ }^{224}$

In essence, this means that the Tweede Kamer tries to argue as much as possible under the subsidiarity heading and other concerns are included, yet more as a general criticism on the proposal. It does not, therefore, extent the scope of subsidiarity but claims a change of EU Treaties as to change the subsidiarity checks into a general political judgment. ${ }^{225}$

\subsection{Outlook}

Assessing the results of the above case-study two conclusions can be drawn. First, most parliaments went beyond the strict interpretation of subsidiarity. Second, there is no common understanding of the principle of subsidiarity.

As to the first conclusion the Commission has announced that it will not undertake a 'judgment call', meaning that it will not dismiss reasoned opinions because NP did not argue under a strict subsidiarity heading and also included concerns as to legal base, proportionality and content. ${ }^{226}$ Assumingly, this will not change soon, yet there is a danger that the more 'yellow cards' are raised and the more national parliaments continue to touch upon the comparative efficiency test only marginally, the Commission might

\footnotetext{
219 Interview with Mrs. Janneke Timmers - Annex II.

220 lbid.

221 lbid.

222 lbid.

223 Ibid.

224 lbid.

225 Ibid.

226 Official Letter Commission 01-12-2009.
} 
rethink its position. While the Commission currently adheres to the subsidiarity strict sensu, it could be argued based on the findings of this paper and other authors, that parliaments interpret subsidiarity of having a broad scope. ${ }^{227}$ There will be a collision of interpretations. The reasons why they interpret subsidiarity differently follows, however, to some extent from their institutional interests. ${ }^{228}$ The Commission finds itself in a 'dilemma of auto- interpretation' as it has to promote the goals of the European Union, but must nevertheless respect the competences of the Member States. ${ }^{229}$ It will therefore, set out an interpretation under which it can prove that a certain legislative proposal respects subsidiarity, an interpretation that is permissive of Union action. ${ }^{230}$ Parliaments, in contrast, want to protect their powers and seem to be interpreting subsidiarity in such way that an infringement can easily be found. ${ }^{231}$ As adumbrated by the analysis of the interpretation of subsidiarity in the Dutch Tweede Kamer, parliamentarians wish to debate the substance of the legislation and its political desirability. ${ }^{232}$ From their point of view an interpretation of subsidiarity is desirable that restricts action at EU level to a large extent. ${ }^{233}$

Thus, an interpretation that can ensure an effective divide between Member State and EU competences has to be found somewhat in between these two opposites. Although inspiration could be taken from the current interpretations of NP and their reasons as to why we should or should not interpret subsidiarity in a certain way, it has to be considered that it remains biased. Usually, parliaments will only issue a reasoned opinion if a crucial political issue is at stake so if the Union encroaches upon traditionally sovereign legislative powers. ${ }^{234}$ There are of course legal arguments why proportionality and legal base could form part of a subsidiarity test, as for example advanced by the German Bundestag, it seems that most parliaments simply include it to underline their general rejection of a legislative proposal.

\footnotetext{
227 Fabbrini \& Granat 2013, p.121.

228 Cooper 2006, p.295.

229 Calliess 2010, p.2.

230 Cooper 2012, p.294.

231 lbid.

232 Paulo 2013, p.11.

233 Cooper 2012, p.295

234 Paulo 2013, p.12 \& 19.
} 
Nevertheless, even among national parliaments there is no uniform interpretation. Some parliaments, as the Belgian Sénat and the German Bundestag, have established their own test coinciding with the broad theory, whereas the UK House of Commons the Dutch Tweede Kamer use the parameters set out in Art.5 (3) TEU and the Protocol attached to the Amsterdam Treaty. However, in order to benefit from the EWS it is essential to develop such a common interpretation. 235 The threshold to raise even a 'yellow card' is relatively high and it needs coordination and networking between the NP to reach this.. ${ }^{236}$ The introduction of the Conference of Community and European Affairs Committees of Parliaments of the European Union (COSAC) has clearly contributed to the exchange of information between NP and subsidiarity issues are frequently discussed at the Monday Morning Meetings. ${ }^{237}$

The Dutch Tweede Kamer, for instance, takes inspiration from its counterparts in other Member States and sometimes adopts parts of their argumentation. ${ }^{238}$ Yet, the yellow card was only raised once and there seem to remain problems of coordination. A common agreement on which criteria should be used to assess subsidiarity compliance could be helpful. A case in point is the Polish Senat's reasoned opinion in the context of Monti II. It only found a breach of proportionality, not subsidiarity and therefore its opinion was not counted. If it, however, had interpreted subsidiarity in light of the test of the Belgian Sénat, an infringement of proportionality would have merely formed part of the broader subsidiarity check. In case of Monti II the opinion was not needed to raise the yellow card, but this could be completely different in other situations or could occur more frequently if NP interpretations' diverge rather than converge. Naturally, NP will find different solutions on how to assess subsidiarity simply due to their diverging political culture, constitutional structure or party system. ${ }^{239}$ Furthermore, even if all parliaments applied the EU-added value test, whether or not EU legislation would have considerable benefits as opposed to national legislation depends on the 'historical, political and social experience' at home.240 The political characteristic of subsidiarity remains.

\footnotetext{
235 Rothenberger \& Vogt 2007, p.6.

236 Paulo 2013, p.8.

237 Paulo 2013, p.16.

238 Interview with Mrs. Janneke Timmers

239 Cooper 2012, p.289.

240 Rothenberge \& Vogt 2007, p.8.
} 
Nevertheless, the initial assumption the substantive interpretation of subsidiarity was irrelevant to national scrutiny procedure has proven to be wrong. ${ }^{241} \mathrm{~A}$ principle that 'cannot be easily validated by operational criteria' as the Commission frames it, was handed to NP who were expected to somehow enhance subsidiarity compliance. ${ }^{242}$ What the above analysis shows is that NP express the need to develop and apply objective criteria. ${ }^{243}$ This can be based on the fact that all four parliaments chosen essentially applied the same parameters to two completely different legislative proposals. The development of these is still at a very early stage, but the value of parliaments' interpretation is undoubtedly their bottom-up approach to subsidiarity.244 Before Lisbon, a top-down perspective on subsidiarity primarily governed the EU institutions. ${ }^{245}$ The ECJ as well as the Commission seemed to equate the presence of an appropriate legal base with a positive subsidiarity appraisal. ${ }^{246}$ If these institution, however, start to value the input of NP in terms of their interpretation of subsidiarity and their insights as to why legislation could be also effectively enacted at national level, this will not only render subsidiarity meaningful but could legitimize the EU as a whole. ${ }^{247}$

\section{Proposed solution - Subsidiarity 3.0}

In this last section, it will be attempted to establish a solution on how subsidiarity should be interpreted in order to form a workable mechanism that ensures and effective divide between Member State and EU competences. Subsequently, an explanation will be provided explaining why this solution has been chosen and a critical assessment of the proposed four theories as well as the solutions chosen in practice will be given.

All interpretations of subsidiarity presented in this paper have approached the matter from the legal perspective. Recently, however, the potential of economic criteria serving as a mechanism to allocate competences between the EU and the Member States was

\footnotetext{
241 Van den Brink 2012, p.176.

$24218^{\text {th }}$ Report on Better Lawmaking in year 2010

243 Van den Brink 2012, p.176.

244 Van den Brink 2012, p.177.

245 lbid.

246 Ibid.

247 lbid.
} 
recognized. ${ }^{248}$ These criteria could repress the current political bargaining that has defined the allocation of competences so far. $^{249}$ Not only does the Commission consider financial aspects in the context of subsidiarity in its Impact Assessment, but also do legal scholars recognize factors such as externalities, economies of scale and information costs as very influential for deciding on centralization or decentralization of regulatory powers. ${ }^{25} \mathrm{~A}$ milestone in this regard, is Van Zeben's test of subsidiarity 2, o. It is derived from the expression of 'scale or effects' in Art.5 (3) TEU. ${ }^{251}$

She proposed this should not be understood as merely referring to the existence of externalities that arise due to certain activities. ${ }^{252}$ This threshold is easily exceeded, since it is always possible to argue that there are externalities, so basically negative effects, caused by trade barriers that appear due to different national laws, be it divergent contract or environmental laws. ${ }^{253}$ An externality would be for instance that consumers have less choice or companies do not engage in trade in other Member States. Thus, simply considering externalities leads to a subsidiarity interpretation that is again highly centralizing. Additional criteria are needed that work against this problem.

Van Zeben takes inspiration from the economic theory of federalism for an appropriate set of criteria for competence allocation. ${ }^{254}$ To start with, the very nature of the regulatory problem establishes which criteria have to be taken into account and how these should be ranked. ${ }^{25}$

Having this in mind, van Zeben proposes a three part test under subsidiarity. Firstly, it still has to be checked whether externalities are present in respect to the regulated activity. If the answer is affirmative, it has to be proven that these externalities are transboundary, meaning that they do not only arise in one Member States but potentially in all 27. Secondly, the level of heterogeneity, meaning conditions and preferences in the different levels (national, regional, local), is assessed. ${ }^{256}$ This part also considers the homogeneity of the causes and effects of a regulatory activity among the jurisdictions in

\footnotetext{
248 Van Zeben 2013, p.3.

249 lbid.

250 Van Zeben 2013, p.20.

251 Van Zeben 2013, p.14.

252 Van Zeben 2013, p.24.

253 lbid.

254 Van Zeben 2013, p.25.

255 Van Zeben 2013, p.26.

256 lbid.
}

Interpreting Subsidiarity - How to develop into a constitutional principle? 
question. ${ }^{257}$ If the preferences and causes are relatively homogeneous, the EU should act. In contrast, if they are heterogeneous there is no added value for the EU to act and Member States retain their competence. Thirdly, economies of scale are part of the test. ${ }^{25}$ In this context, it has to be decided what information has to be collected in order to regulate an action. 259 If the scope of information is determined it has to be assessed at which level the gathering of information would be more or less costly. ${ }^{260}$ If it is cheaper on a local level, then the regulatory activity should be decentralized. Generally, it can be useful to equally consider whether negative effects become manifest immediately or at a later date and which groups are affected and involved in the activity. ${ }^{261}$

This test could potentially cure the defects of the comparative efficiency test, since it sets out real objective criteria to assess what 'EU added value' is and to avoid overcentralization. It will not be possible for the Commission to simply argue that a measure of harmonization cannot be achieved by action at national level and that the presence of externalities supports this. It demands more than that. The first and the second step include what is essentially the cross-border-activity test proposed by AG Maduro. Only if these transnational aspects are present, considerable and cannot be regulated by Member States in due time, competence should be allocated to the EU. Furthermore, it has to be proven that the effects and causes of the problem are so heterogeneous, that alignment on central level becomes inevitable.

Nevertheless, the arguments brought forward by the representatives of theory in which subsidiarity and proportionality are to some extent coupled are very strong. Can subsidiarity by itself, even if we consider the above factors, avoid that the EU, for instance, decide to have English as the only language in the EU? Probably not; the proposed model could, therefore, benefit from a fourth tier in which we undertake a non-encroachment check. ${ }^{262}$

In this regard, Schütze's idea of federal proportionality asking whether the EU legislator has unnecessarily restricted or encroached upon national autonomy could be of real value. This would allow proportionality to remain a separate principle, and only the overlapping

257 lbid.

258 lbid.

259 lbid.

260 lbid.

261 lbid.

262 See Gustaferro 2013 
aspect of it could be included in a subsidiarity analysis. Even in the Treaties we can find support for this. Art.4 (2) TEU protects the Member States' national identities, including their fundamental structure and the respect for essential State functions. ${ }^{263}$ If one takes a look at the intention of the drafters, it seems that it was supposed to address the same concerns, namely protection Member States' autonomy against an EU competence creep, as subsidiarity. ${ }^{264}$ The case study on parliaments' interpretation supports this need as most of them argued that the proposal in question was not necessary to attain the objective. If they could argue that there were neither transnational aspects nor sufficient need to encroach upon their competences, this demand could be satisfied.

It should be avoided to extent subsidiarity to far, as so interpret it in the sense of the whole Art.5 TEU. Although all three principles clearly interrelate, they should be separated. The Union needs to prove that it has competence and chose the correct legal base before it is possible to engage in a subsidiarity analysis. If there is no legal base, then competences cannot be allocated to the Union level. If there is however a legal base, the current approach of the ECJ and Commission should however be avoided as to equate the two. Both should nevertheless engage in a detailed subsidiarity analysis that addresses the question of 'should' the EU act. With regard to proportionality, an overlap is undeniable and incorporating aspects of it into subsidiarity useful, but the question of how the EU should act, in the sense of which instrument is distinct from this. If the ECJ is, for instance, considering whether a protectionist measure is proportionate, it will also not undertake a subsidiarity analysis. The underlying argument is that subsidiarity cannot develop into this workable mechanism if we devalue it by simply confusing and replacing in by other principles.

Lastly, whether or not Protocol No.2 should be extended to a proportionality review as well is a complete different question.

By using these objective criteria in conjunction with federal proportionality, potentially a workable mechanism could develop. To prove this further, research has to be conducted. But it is a first step in the right direction. It seems that the time has come to operationalize subsidiarity not only to enhance the review by national parliaments.

263 See Gustaferro 2013, p.5.

264 Gustaferro 2013, p.6 


\section{Conclusion}

For a principle that has emerged since the very beginnings of the European Union, subsidiarity has been of almost no significance in the last decades. The two main reasons for this are clearly its drafting history and the Court's continuing reluctance maybe even unwillingness to operationalize this predominantly political principle in legal terms. What started out as an alibi to tranquilize the Eurosceptic movement in the 1990 s was more and more recognized as a useful tool to balance the powers between Member States and the EU. Although guidance was provided by the Commission and the European Council in the following years, an interpretation satisfying and fair to all actors seemed to be an impossible task.

Academia has identified this problematic already at an early stage and underlined the drawbacks of the comparative efficiency test. In fact, the wording of Art.5 (3) TEU is highly centralising and has rendered it easy for the Commission to justify its action. The rationale behind subsidiarity, however, is that actions are taken as the lowest level possible in order to ensure closeness to the people. The prerequisite for a workable competence allocation in the sense of traditional subsidiarity is still a common goal. The EU and the Member States often lack this. It seems that subsidiarity has to be adapted as Member States want to protect their national autonomy, yet benefiting from the strength of common action in, for instance, monetary or immigration policy. There remain subjective aspects to this, but a principle of constitutional value should be possible to assess in a legal and objective form.

The three theories presented attempt this. The presence of cross-border activity seems to be valuable as purely national concerns remain protected and only those area in which Member States are so closely linked and problems can inevitably not be solved in isolation could benefit from common action. Expanding subsidiarity towards proportionality could even enhance this by making legislators aware of the necessity of every action and its importance to respect national identities. The broad interpretation, in contrast, addresses the competence of the EU more generally and not so much an optimal allocation. It seems that not drawbacks of subsidiarity are cured, but more promising and stronger principles are used instead.

Moving to the practice of subsidiarity many findings can be noted. Although the Court seems to have become more confident in its reviewing over time and has stated that the principle is clearly justiciable, there is only Tobacco Advertising in which the Court has undertaken a deeper analysis. In this case, it has to come extent adopted the cross-border activity test, but in every prior and subsequent case it has gone back to its routine. Not only is subsidiarity 
equated with the correct legal base, but also is its EU added value test very one-sided. The legislator is left wide discretion.

It is legitimate to place hope into the new actor reviewing subsidiarity, namely the national parliaments. They offer a new perspective in this area and are currently in the stage of developing objective criteria. Cleary their concerns are allegedly biased and frameworks not yet uniform but they have not only the potential to influence the EU legislator at an early stage, but also to offer the Court input. The EWS is only four years old, so if they can manage to merge their interpretations into a workable mechanism, subsidiarity can gain significance.

The proposed model of this paper tries to set out a model for them and the other institution that indeed needs to be tested in practice. Combing the lessons learned from theory and practice it can potentially make subsidiarity a meaningful and independent principle. Economic criteria can be used to describe the phenomena of transnational aspects and the fourth tier adapts subsidiarity to the need of protecting national autonomy

If all actors dearly contribute to this process of finding a suitable interpretation, subsidiarity could metamorphose from this ambiguous notion into fundamental principle of EU law. 


\section{Bibliography}

\section{Primary Souces:}

\section{Ares 20121058907}

- Commission decision to withdraw the Proposal for a COUNCIL REGULATION on the exercise of the right to take collective action within the context of the freedom of establishment and the freedom to provide services - $\operatorname{COM}(2012) 130$

\section{CONV 286/02}

- Chairmon of the Working Group I on the Principle of Subsidiarity Members of the Convention; Conclusion of Working Group I on the Principle of Subsidiarity, 23 September 2002

\section{House of Commons 33 ${ }^{\text {rd }}$ Report 2008}

- European Scrutiny Committee; Subsidiarity, National Parliaments and the Lisbon Treaty. $33^{\text {rd }}$ Report of Session 2007-08

Impact Assessment Guidelines 2000

- SEC(2009) 92 - European Commission - Impact Assessment Guidelines, January 2000. Official Letter Commission 01-12-2009

- Including practical arrangements for the operations of the subsidiarity control mechanism under Protocol No.2 of the Treaty of Lisbon

Political Guidelines for the next Commission 2009

- José Manuel Barroso; Political Guidelines for the next Commission, September 2009

Unterausschuss Europarecht Protokoll Nr.8 2010

- Deutscher Bundestag Protokoll der 8. Sitzung des Rechtsausschusses Unterausschuss Europarecht; Öffentliches Expertengespräch zum Thema: Prüfung des unionsrechtlichen Subsidiaritätsprinzips. Vorsitzender Dr. Patrick Sensburg $-16^{\text {th }}$ June 2010

\section{Working Group I Working Document 11 - European Convention}

- Working Group 1 on the Principle of Subsidiarity 2002, Subject: Making the Subsidiarity operational - paper by Mr. Hannes Farnleiter and Mr. Reinhard E. Bösch, 12 August 2002

$18^{\text {th }}$ Report on Better Lawmaking 2010

- Subsidiarity and Proportionality Report 2010, COM(2011)344 


\section{Secondary Sources:}

\section{Biondi 2012}

- Andrea Biondi, 'Subsidiarity in the Courtroom', in: Biondi et al., (Eds); The EU after Lisbon. New York: Oxford University Press, 2012

\section{Cass 1992}

- Deborah Z. Cass; The Word That Saved Maastricht? The Principle of Subsidiarity and the Division of Powers within the European Community', Common Market Law Review 29, 1992, pp.1112-1116

\section{Chalmers 2010}

- Damian Chalmers; European Union Public Law - Cases and Materials. Cambridge: Cambridge University Press, 2010

\section{Constantin 2008}

- Simona Constantin; Rethinking Subsidiarity and the Balance of Powers in the EU in Light of the Lisbon Treaty and Beyond. Croatian Yearbook of European Law and Policy (4), 2008, pp.151-177

\section{Cooper 2006}

- Ian Cooper; The Watchdogs of Subsidiarity: National Parliaments and the Logic of Arguing in the EU. Journal of Common Market Studies 44 (2), 2006, pp.281-304

\section{Cooper 2012}

- Ian Cooper; A 'Virtual Chamber Third Chamber' for the European Union? National Parliaments after the Treaty Of Lisbon. West European Politics 35 (3), 2012, pp.441-465

\section{Craig \& De Búrca 2011}

- Paul Craig \& Gráinne De Búrca; EU Law - Text, Cases, And Materials. $5^{\text {th }}$ edition. New York: Oxford University Press, 2011

Davies 2006

- Gareth Davies; Subsidiarity: The Wrong Idea, in the Wrong Place, at the Wrong Time. Common Market Law Review 43, 2006, pp. 63-84

\section{Dashwood 2004}

- Alan Dashwood; The Relationship between the Member States and the European Union/European Community. Common Market Law Review 41 (2), 2004, pp.355-381

\section{De Búrca 1998}

- Gráinne De Búrca; The Principle of Subsidiarty and the Court of Justice as an Institutional Actor. Journal of Common Market Studies 36 (2), 1998, pp.217-234 


\section{Emiliou 1994}

- Nicholas Emiliou, 'Subsidiarity Panacea or Fig Leaf?' in: David O’Keeffe \& Patrick Twomey (Eds); Legal Issues of the Maastricht Treaty. Chichester: Chancery Law Publishing Ltd, 1994 Estella 2002

- Antonio Estella; The EU Principles of Subsidiarity and its Critique. Oxford: Oxford University Press, 2002

Fabbrini \& Granat 2013

- Frederico Fabbrini \& Katarzyna Granat; The Yellow Card, but no Foul: The Role of the National Parliaments under the Subsidiarity Protocol and the Commission Proposal for an EU Regulation on the Right to Strike. Common Market Law Review 50, 2013, pp.114-144

\section{Gustaferro 2013}

- Barbara Gustaferro; Reframing Subsidiarity Inquiry From and "EU Value Added" to and "EU Non-Encroachmen" Test?: Some Insights from National Parliaments Reasoned Opinion. Working Paper Serien - School of Government Luiss Guido Carli

Hettne \& Langdal

- Jörgen Hettne \& Frederic Langdal; Does Subsidiarity Ask the Right Question?. Think Global . Act European Part VIII - Institutional Innovations

Horsley 2011

- Thomas Horsley; Subsidiarity and the European Court of Justice: Missing Pieces in the Subsidiarity Jigsaw? Journal of Common Market Studies, 2011, pp.1-16

Horspool \& Humphrey 2012

- Margot Horspool \& Matthew Humphrey; European Union Law. $7^{\text {th }}$ edition. Gasport: Oxford University Press, 2012

Kiiver 2011

- Philipp Kiiver; The conduct of subsidiarity checks of EU legislative proposals by national parliaments: anaylsis, observations and practical recommendations. Europäische Rechtsakademie Forum, 2011

\section{Kumm 2006}

- Mattias Kumm; Constitutionalising Subsidiarity in Integrated Markets; The Case of Tobacco Regulation in the European Union. European Law Journal 12 (4), 2006, pp.503-533 Low 2011

- Gary W.L. Low; European Contract Law between the Single Market and the Law Market - A Behavioural Perspective. Nijmegen: Wolf Legal Publishers, 2011 


\section{Martinico 2010}

- Giuseppe Martinico; Dating Cinderella: On Subsidiarity as a Political Safeguard of Federalism in the European Union. Working Paper No.2/2010, Institut de Dret Públic Universitat de Barcelona

\section{Marquardt 1994}

- Paul D. Maruqardt; Subsidiarity and Sovereignty in the European Union. Fordham International Law Journal 18 (2), 1994, pp.616-640

Paulo 2012

- Maria Teresa Paulo; National Parliaments in the EU: after Lisboa and beyond subsidiarity - the (positive) side-effects and (unintended) achievements of the Treaty Provisions. OPAL Online Paper No.5/2012

\section{Rothenberger \& Vogt 2007}

- Stefanie Rothenberge \& Oliver Vogt; The "Orange Card": A fitting Response to National Parliaments' Marginalisation in EU-Decision-Making. Paper prepared for the Conference "Fifity Years of Interparliamentary Cooperation", 13 June 2007, Bundesrat, Berlin, organised by the Stiftung Wissenschaft und Politik

\section{Schütze 2009}

- Robert Schütze; Subsidiarity after Lisbon: Reinforcing the Safeguard of Federalism? Cambridge Law Journal 68 (3), 2009, pp.525-536

\section{Türk 2009}

- Alexander H. Türk; Judicial Review in EU Law. Cheltenham: Edward Elgar Publishing Limited, 2009

\section{Van den Brink 2012}

- Tom van den Brink, 'The substance of subsidiarity: the interpretation and meaning of the principle after Lisbon' in: Martin Trybus \& Luca Rubini (Eds); The Treaty of Lisbon and the Future of European Law and Policy. Cheltenham: Edward Elgar Publishing, 2012 Van Zeben 2013

- Josephine van Zeben; Subsidiarity 2,0? Competence Allocation in EU Environmental Law. Not yet published

Weatherill 2010

- Stephen Weatherill, 'Competence and European Private Law' in: Christian TwiggFlesner (Eds); Cambridge Companion on European Union Private Law. Cambridge: Cambridge University Press, 2010 


\section{Weatherill 2011}

- Stephen Weatherill; The Limits of Legislative Harmonization Ten Years after Tobacco Advertising: How the Court's Case Law has become a "Drafting Guide". German Law Journal 12 (3), 2011, pp.827-864

\section{Wyatt \& Dashwood 2011}

- Derrick Wyatt \& Alan Dashwood; European Union Law. $6^{\text {th }}$ edition. Oxford: Hart Publishing, 2011

\section{Internet sources:}

\section{Calliess 2010}

- Christian Calliess; Schriftliche Stellungnahme zum öffentlichen Expertengespräch des Unterausschusses Europearecht des Rechtsausschusses des Deutschen Bundestages zum Thema Prüfung des unionsrechtlichen Subsidiaritätsprinzp, Berlin, 2010

Retrieved via

http://www.bundestag.de/bundestag/ausschuesse17/ao6/ua_europarecht/

anhoerungen/o1_Subsidiaritaet/o2_Stellungnahmen/Stellungnahme_Calliess.pdf

(last visited 26-06-2013)

European Parliament website on 'subsidiarity'

- Retrieved via:

http://circa.europa.eu/irc/opoce/fact_sheets/info/data/how/characteristics/article_7148_en.htm (last visited 26-06-2013)

Reasoned Opinions (all last visited 09.07.2013)

- Proposal for a Council Regulation on the right to take collective action within the context of the freedom of establishment and the freedom to provide services

- Reasoned Opinion Dutch Tweede Kamer retrieved via http://Www.ipex.eu/IPEXL-WEB/scrutiny/APP20120064/nltwe.do

- Reasoned Opinion Swedish Riksdag retrieved via http://www.ipex.eu/IPEXL-WEB/scrutiny/APP20120064/serik.do

- Reasoned Opinion Polish Sejm retrieved via http://www.ipex.eu/IPEXL-WEB/scrutiny/APP20120064/p/sej.do

- Reasoned Opinion Maltese House of Representatives retrieved via http://Www.ipex.eu/IPEXL-WEB/scrutiny/APP20120064/mtkam.do

- Reasoned Opinion Luxembourg Chambre de Députés retrieved via http://Www.ipex.eu/IPEXL-WEB/scrutiny/APP20120064/luchb.do 
- Reasoned Opinion Latvian Saeima retrieved via http://Www.ipex.eu/IPEXL-WEB/scrutiny/APP20120064/Ivsae.do

- Reasoned Opinion Danish Folketinget retrieved via http://Www.ipex.eu/IPEXL-WEB/scrutiny/APP20120064/dkfol.do

- Reasoned Opinion Finish Eduskunta retrieved via http://Www.ipex.eu/IPEXL-WEB/scrutiny/APP20120064/fiedu.do

- Reasoned Opinion UK House of Commons retrieved via http://Www.ipex.eu/IPEXL-WEB/scrutiny/APP20120064/ukcom.do

- Reasoned Opinion Portuguese Assembleia da República retrieved via http://Www.ipex.eu/IPEXL-WEB/scrutiny/APP20120064/ptass.do

- Reasoned Opinion Belgian Chambre des Représentants retrieved via http://Www.ipex.eu/IPEXL-WEB/scrutiny/APP20120064/bechb.do

- Reasoned Opinion French Sénat retrieved via http://Www.ipex.eu/IPEXL-WEB/scrutiny/APP20120064/frsen.do

\section{Common European Sales Law}

- Reasoned Opinion Austrian Bundesrat retrieved via http://www.ipex.eu/IPEXL-WEB/scrutiny/COD20110284/atbun.do

- Reasoned Opinion Belgian Sénat retrieved via http://www.ipex.eu/IPEXL-WEB/scrutiny/COD20110284/besen.do

- Reasoned Opinion German Bundestag retrieved via http://www.ipex.eu/IPEXL-WEB/scrutiny/COD20110284/debta.do

- Reasoned Opinion UK House of Commons retrieved via http://Www.ipex.eu/IPEXL-WEB/scrutiny/COD20110284/ukcom.do 
Annex I

COM (2012)13 final - Proposal for a Council Regulation on the right to take collective action within the context of the freedom of establishment and the freedom to provide services (Monti II)

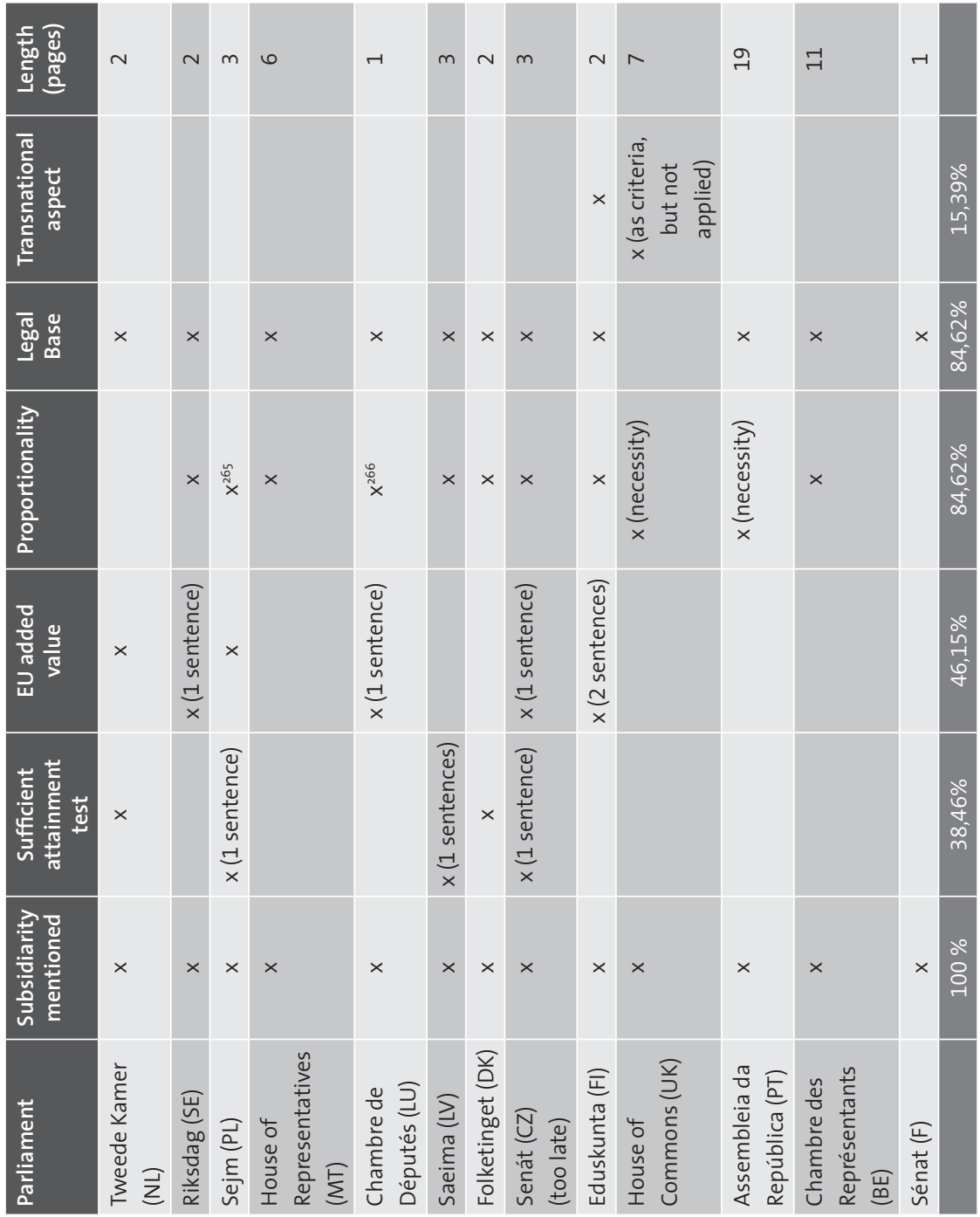

265 Recommendation would have been sufficient

266 Includes added value to come extent 
$\operatorname{COM(2011)~} 635$ final - Proposal for Regulation of the European Parliament and of the Council on a Common European Sales Law (CESL)

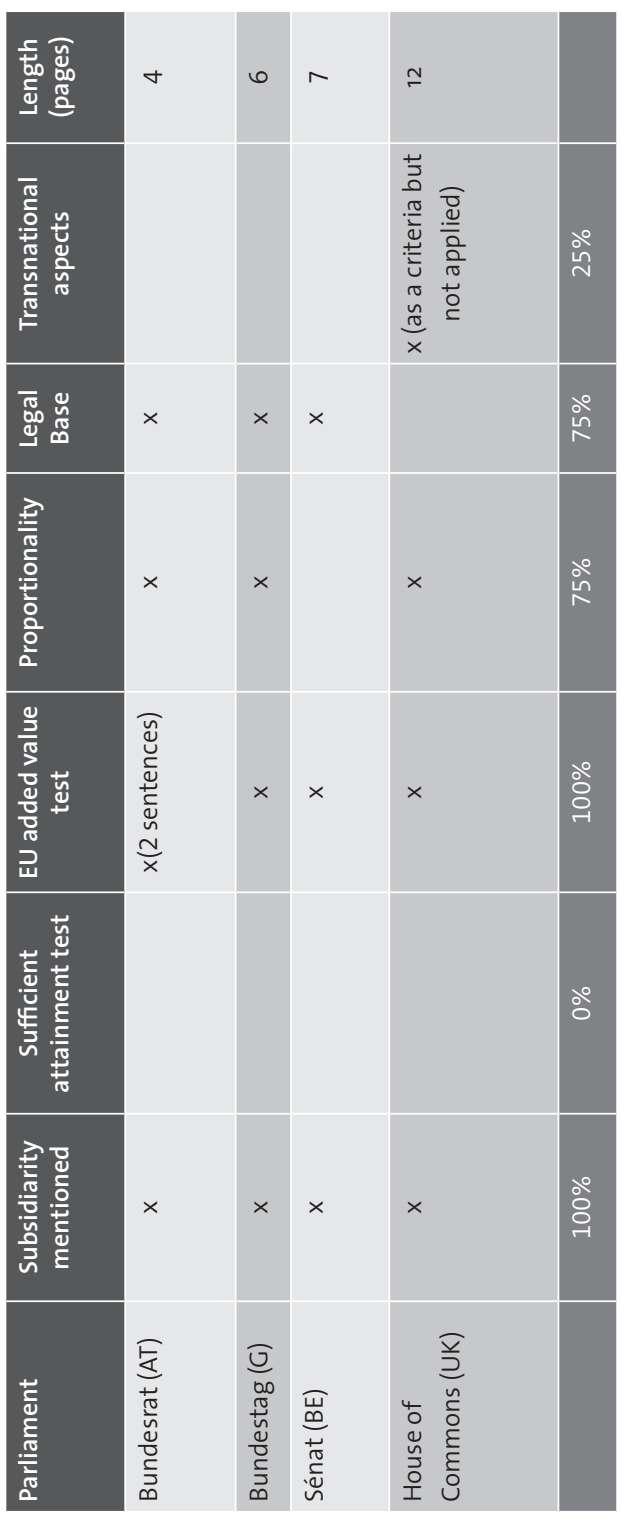




\section{Annex II}

\section{EU- Advisor Committees on Security and Justice and on Education, Culture, Science and Emancipation Tweede Kamer}

S. Gernat: 'Good afternoon Mrs. Timmer. I am currently writing my Bachelor thesis about the interpretation of subsidiarity in the national parliaments with a focus on the Common European Sales Law and the Monti II Regulation. My first question would be if you have general information on that.'

Ms. Timmer: 'I have to say that I am not familiar with these two proposals in particular, but I can tell how the Tweede Kamer is dealing with the subsidiarity check in general. Would you like to know something in particular?'

S. Gernat: 'That would be great. Thank you. Does the Tweede Kamer have specific criteria on how they assess subsidiarity compliance? To what extent does it look at other aspects, such as the legal basis and the principle of proportionality?'

Ms. Timmer: 'Maybe I can answer your question and explain you a little on how we deal with the check generally. Yes, we have criteria. What we normally do is we as the EU staff look at the proposal and we prepare the members of parliament doing the subsidiarity check. If they want to do it, we explain to them what they should look at. You could call this the criteria. In a subsidiarity check we look at whether it has been proved convincingly that European action has an added value compared to national policy. So, we explain that the question is at stake whether the goals of the EU proposals cannot be reached by the Member States themselves and whether they can be better reached on the level of the European Union. For example if it can be attained where there is a situation that covers more than one country. It is passing the borders of the country and affects, for instance, the internal market. Those things are logically done at the European level. That is how we deal with it. I will just look at one of my preparations for a subsidiarity check. The EU is only allowed to deal with a certain matter, if it can do it more efficiently than on a national level. If the action of the Commission covers themes that do not fall under the exclusive competence of the EU, then the Commission will only act if the MS cannot realize the goals themselves or can better act due to the extent or the consequences of the action. Then we also explain that they have to look at certain questions: Is it dealing with transnational aspects that cannot be dealt with by Member States themselves? Would 
actions by Member States alone or lack of Community action conflict with the requirements of the Treaty or otherwise significantly damage Member States' interests? Does action on EU level have clear advantages compared to the national level,'

S. Gernat: 'These criteria therefore conform with the guidelines mentioned in the Protocol on the application of subsidiarity and proportionality attached to the Amsterdam Treaty, correct?'

Ms. Timmer: 'Yes, exactly. Now, I would like to move to the procedure in the Tweede Kamer. Normally the Commission starts in October or November of every year with publishing the working program of the Commission for the next year. On the basis of this working program, the parliament can already look at what is proposed for the coming year and if there are certain proposals that they think should have priority. They can establish on which items they should look more carefully. We call these the European priorities. When we are scrutinizing the European Commission's program, the members of parliament also look at whether the European proposal will be of such an importance that they want to have a subsidiarity check on it or a parliamentary scrutiny reserve. The latter is an instrument to control the government. We do not use the instrument of parliamentary scrutiny reserve towards the European Commission, but use it in order to make sure that the parliament will be well informed by the government on the European issues. If members of parliament believe that a certain proposal is of big political importance, they can request to conduct a parliamentary scrutiny reserve and in that case there will be a separate debate only on this proposal very quickly after the proposal has been published. The debate will be about the position of the government on the proposal and on how parliament will stay informed. The result is an agreement on how the government will inform parliament about among others the negotiations, about the stance of the government during negotiations and their possible changes of position.'

As regards the subsidiarity check, when they have done the scrutinizing of the work program, they have a list of EU priorities. There are little crosses behind each proposal indicating the intention of having either a subsidiarity check or a parliamentary scrutiny reserve. That is really useful also in order to talk with other national parliaments well in advance of the publishing of the European proposals to make sure that parliaments know what the Dutch parliament is planning to do on a certain proposal. This is important because if we conduct a subsidiarity check we only have eight weeks to do it and that is a very short time in parliament. If we are doing a subsidiarity check, it is useful that more than one national parliament is also doing the check so that we could be able to get the yellow card. But this has of course happened only one time and is, therefore, not very successful yet. We have to improve our cooperation with other national parliaments so that we can be better prepared to cooperate together.' 
S. Gernat: 'Interesting. So the criteria you are using are basically from the Amsterdam guidelines, but in the reasoned opinion on the Monti II Regulation, the Tweede Kamer also looked at the legal base of the proposal. On what basis do parliamentarians chose what they are going to assess? You mentioned earlier that the criteria you use refer more to subsidiarity in the strict sense, but why did they then also assess the legal base?'

Ms. Timmer: 'The legal base is mostly the first thing we look at. If there is no legal base for the Commission, national parliaments are of course not in favor of the proposal at all. The legal base is therefore the first step in our analysis. Then we look at the subsidiarity of the proposal if the legal base is the right one.'

S. Gernat: 'The reason why I am asking is that Art.5 (3) TEU only addresses subsidiarity in the strict sense. However, my findings have shown that national parliaments go beyond that scope and assess whether the EU has competence to act. The Tweede Kamer, therefore, also conducts a competence check first and then goes more into subsidiarity itself, did I understand that correctly?'

Ms. Timmer: 'Yes, that is correct. To say a little bit more, because I saw in your question that you sent me beforehand that you would like to know whether the Tweede Kamer looks into proportionality as well and whether they define the principle politically or legally. I must say if you ask politicians for their opinion, you will never get legal arguments; you will of course receive political arguments. I think that this is the case in many countries. We have discussed this last year with civil servants from other parliaments. We found that there is really a big tendency for politicians to not look at the legal arguments, but to more or less argue whether the proposal is something they want or not. Of course they understand that reasoned opinions have to be written in a legal way, since it is a legal instrument. We are, at the moment, by the way internally evaluating the way we are dealing with the subsidiarity check and conduct interviews with parliamentarians in this context. Many parliamentarians complain that they do not want this to be legal, but they want to make a political judgment. Some parliamentarians even say that we should try to change the treaty or try to make sure that they can have a political say instead of only a legal one. But this is not the case yet.'

S. Gernat: 'Yes, this is probably in line with the general belief that subsidiarity is in essence a political principle. Do you think that a missing uniform interpretation of subsidiarity and divergences in reasoned opinions of national parliaments forms a barrier to cooperate?' 
Mrs. Timmer: 'It could be very useful for you to check documents of COSAC in this regard as they have done a publication last year exactly on this question. My personal opinion is that it could be very useful to have a common agreement on subsidiarity, but it could be even more useful to have an agreement on how we deal with it. I had the impression that there a countries that often do subsidiarity checks and there are countries that hardly do so or have never done one. I think it could be problem for their staff to act quickly due to internal reasons. Both a common definition and a common approach on how to deal with these checks more quickly could help. It is also desirable to have a longer period to assess subsidiarity. Eight weeks are very short and we frequently receive complaints from other parliaments that certain things cannot be done in this short period. Let us assume that a proposal has been published a week before the summer holidays then eight weeks can pass by quickly. I was personally involved in a subsidiarity check where the proposal was submitted to us mid-November and eight weeks later would have been the $15^{\text {th }}$ January. Many countries and their national parliaments have Christmas holidays, varying between two to four weeks, so that the time period is reduced to a considerable extent.'

S. Gernat: 'It is probably also very difficult to coordinate between parliaments, if this period is suddenly that short. Another question is how far the Tweede Kamer takes inspiration from other parliaments in their reasoned opinions. Does it look at their argumentation as well?'

Ms. Timmer: 'Yes, they do that. This depends a little of course, because sometimes an issue is deemed to be so important in the Netherlands that we try to be extremely quick in our subsidiarity check. This can result in a situation where we are the second or first parliament ready so we cannot really look at other parliaments' argumentation. But we can send our conclusions to them and help them in their argumentation. In other cases, it works the other way around so that we have the possibility to orient ourselves on them. It is, however, always a bit difficult. Normally, we ask all the parties in parliament to write down their argumentation for the subsidiarity check. Not all eleven parties will answer this, but usually we get four to six responses in which parties write down their argumentation on why this specific proposal is contrary to the subsidiarity principle. Their argumentations are sometimes very wide and if the parties have not seen the reasoning of other parliaments then we normally stick to the argumentation of the parties itself. As staff we cannot make up additional arguments. But if other parliaments are very quick we can even use their argumentation for our preparation of the subsidiarity check. We prepare parties for doing the subsidiarity check by writing down its definition, what the Commission is arguing and possibly what other parliaments have come up with.' 
S. Gernat: 'Coming back to the procedure in the Tweede Kamer. Basically, you submit your preparations to the parties and then they provide you with their own argumentation. Does this mean that their argumentation could be different since they do not necessarily apply the same criteria?'

Ms. Timmer: 'That is true. What I normally do, but this can differ, is to see if their argumentation fits legally and then I start with that in the reasoned opinion. Sometimes this is difficult as their complaints are very important, but not legal. I will nevertheless write these down. That is why reasoned opinions are not always $100 \%$ based on legal argumentation. It contains legal information and information that is important enough to submit to the European Commission.'

S. Gernat: 'You mentioned earlier that parliamentarians argue in a political way and do not restrict themselves to the subsidiarity criteria you named above. Is it therefore likely that they look at proportionality compliance as well?'

Ms. Timmer: 'Yes, that is true and happens sometimes. I know that there is a whole discussion about whether proportionality should be also part of the whole check. That is also in the COSAC at the moment. The opinion of the Dutch parliament is that proportionality should also be part of the check. It is a strange split between the two principles. Normally the Treaties refer to subsidiarity and proportionality in one line, but then they are separated in the Protocol. We are only allowed to talk about subsidiarity. There are many members of parliaments who know they are limited to subsidiarity yet wanting to express their concerns about proportionality as well. When I draw up the reasoned opinions I generally take into account that the Commission will argue that this is a subsidiarity check only. Thus, I try to separate it and add a paragraph on proportionality.'

S. Gernat: 'But this would still be included in the reasoned opinions?'

Ms. Timmer: 'Yes. The definition of proportionality is not strictly defined. Sometimes I simply describe it. They may not always assess it, but if there is a proportionality issue, we will describe this in the reasoned opinion.'

S. Gernat: 'How do you deal with the fact that the Commission in one of its official letters stated that they will not do a judgment call, meaning that they will not dismiss reasoned opinions because they failed to argue strictly under a subsidiarity heading? Does the Tweede Kamer take this into account?' 
Ms. Timmer: 'Yes, we take this into account. Normally, we also get an answer from the Commission. I cannot really say if the Commission also addresses all the other issues brought forward in its answer to all our reasoned opinions. I think, it is good that they look at the other arguments anyway so there is no disincentive for us to put them.'

S. Gernat: 'That is why I am asking since this provides the Tweede Kamer with more room for argumentation.'

Ms. Timmer: 'I have to say, however, that we always address the subsidiarity issue and then in addition also legal base and proportionality.'

S. Gernat: 'So you try to be as close as possible to the strict subsidiarity test?'

Ms. Timmer: 'Yes, but the difficult thing with politicians is to 'direct' them. We inform them about the procedures of a subsidiarity check and its criteria. If they want something else in the opinion, an argument that is not concerned with subsidiarity, they will get their way eventually. Even though it is not a subsidiarity argument, they will want to incorporate it.'

S. Gernat: 'My last question is that if we assume that the Tweede Kamer would draw up a checklist on subsidiarity and submit it to the parliamentarians, do you think that would help them or would they nevertheless add their own political arguments?'

Ms. Timmer: 'We have something that comes close to a checklist, but it is not something that you can cross. We use the criteria I referred to earlier in our preparations for the parliamentarians so that they could use it as a checklist on what they should address and I think that helps them to stay as close as possible to subsidiarity. Some parliamentarians just read that and state that this is also their opinion. We also have a checklist for the EU staff. We have a checklist on the whole procedure, stating what to do when. This helps us and we try to inspire other parliaments to adopt a similar procedure.'

S. Gernat: 'Thank you very much for all these information and your openness.'

Ms. Timmer: 'Thank you, too and I hope I was able to help you.' 